\title{
C-Glycosylflavones Alleviate Tau Phosphorylation and Amyloid Neurotoxicity through GSK3 $\beta$ Inhibition
}

\author{
Zhibin Liang $^{\dagger}$, Bei Zhang ${ }^{\dagger}$, Wei Wen Su ${ }^{\dagger}$, Philip G. Williams ${ }^{\ddagger}$, Qing X. Li ${ }^{\star}{ }^{\dagger}$ \\ † Department of Molecular Biosciences and Bioengineering, University of Hawaii at Manoa, \\ Honolulu, Hawaii 96822, United States \\ ‡ Department of Chemistry, University of Hawaii at Manoa, Honolulu, Hawaii 96822, United States
}

\begin{abstract}
Alzheimer's disease (AD) is the most common brain disorder worldwide. The aberrant tau hyperphosphorylation and accumulation play a critical role in the formation of neurofibrillary tangles highly associated with neuronal dysfunction and cognitive impairment in AD pathogenesis. Glycogen synthase kinase- $3 \beta$ (GSK3 $\beta$ ) is a key kinase responsible for tau hyperphosphorylation. Selective inhibition of GSK3 $\beta$ is a promising strategy in AD therapy. Corn silks (CS, Zea mays L.) have been traditionally used as a medicinal herb and recently noted for their potentially cognitive benefits. However, the neuroprotective components of CS and their molecular mechanism have received little attention to date. As part of our efforts screening phytochemicals against a broad panel of kinases targeting AD tauopathy, we found inhibition of GSK3 $\beta$ by CS extracts. Subsequent bioassay-guided fractionation led to the isolation and identification of two 6- $C$-glycosylflavones, isoorientin (1) and 3'-methoxymaysin (2), with selective inhibition against GSK3 $\beta$ in vitro. Enzyme kinetics and molecular docking studies demonstrated that 1 specifically inhibited GSK3 $\beta$ via an ATP noncompetitive mechanism, acting as a substrate competitive inhibitor of GSK3 $\beta$. Further in vitro cellular studies demonstrated that 1 effectively attenuated tau phosphorylation mediated by GSK3 $\beta$, and was neuroprotective against $\beta$-amyloid induced tau hyperphosphorylation and neurotoxicity in SH-SY5Y cells. The $C$ glycosylflavones represent new lead candidates with a novel mechanism of action for the development of $\mathrm{AD}$ phytopharmaceuticals.
\end{abstract}

\section{Graphical Abstract}

\footnotetext{
*Corresponding Author qingl@ hawaii.edu; Fax: (808) 965-3542.

Author Contributions

Z.L. and Q.X.L conceived, designed experiments and performed data analysis and interpretation. Z.L. performed experiments. B.Z. conducted immunoblot analysis. W.W.S., P.G.W. and Q.X.L. contributed reagents/materials/analysis tools and assisted in data acquisition. Q.X.L. conceived the research. The manuscript was written through contributions of all authors.

The authors declare no competing financial interest.

ASSOCIATED CONTENT

Supporting Information. Additional figures as described in the text. This material is available free of charge on the Internet at http:// pubs.acs.org.
} 


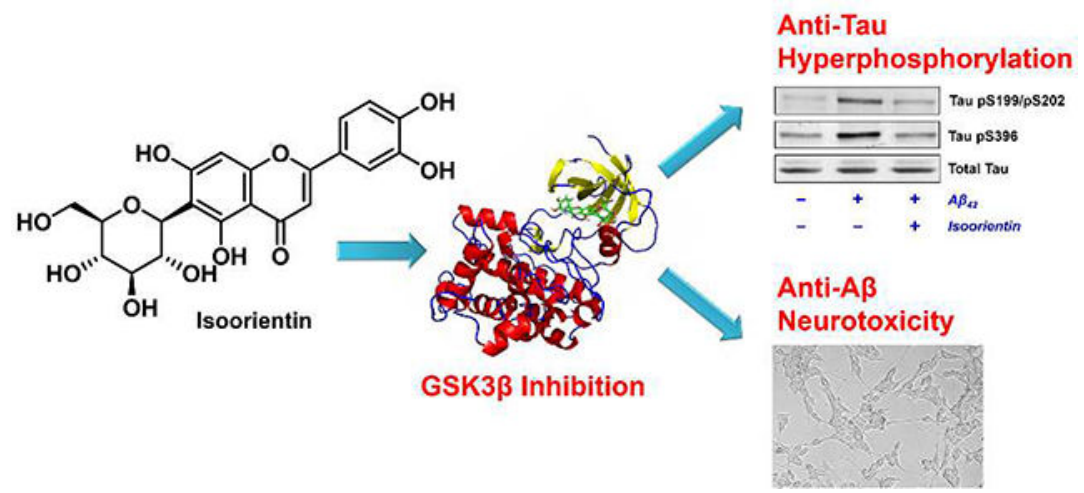

\section{Keywords}

C-Glycosylflavone; Alzheimer; neuroprotection; tau phosphorylation; amyloid; GSK3

\section{INTRODUCTION}

Alzheimer's disease (AD) is a progressive and irreversible neurodegenerative disease that causes memory loss and cognitive impairment in conjunction with mental and behavior changes. While the exact etiology is still uncertain, the current evidence indicates that the formation of neurofibrillary tangles (NFTs) and $\beta$-amyloid (A $\beta$ ) plaques accompanied by synaptic dysfunction and neuroinflammation are the molecular characteristics of AD. ${ }^{1-2}$ NFTs aggregated by intracellular hyperphosphorylated tau proteins are one of the major hallmarks in the pathology of AD. Tau protein, an important microtubule-associated protein, stabilizes the integrity and functionality of microtubules in the neuronal cytoskeleton, and maintains healthy axonal transport. ${ }^{3}$ In $\mathrm{AD}$, abnormal phosphorylation of tau attenuates their binding to microtubules in neurons, leading to microtubule destruction and neuronal dysfunction. Self-assembly of dissociated tau results in the formation of neurotoxic paired helical filaments (PHFs) as well as hyperphosphorylated NFTs. This collectively aberrant signaling cascade is thought to contribute to the eventual neuronal cell death and declined cognition, giving rise to the "tau hypothesis of $\mathrm{AD}$ ". $4-5$

Many tau-protein kinases (TPKs) and microtubule affinity-regulating kinases (MARKs) mediate tau phosphorylation. ${ }^{6}$ Among them, glycogen synthase kinase- $3 \beta$ (GSK3 $\beta$ ) is one of the most relevant kinases for aberrant tau phosphorylation in AD. In AD brains, a number of GSK3 $\beta$ phosphorylation sites flanking the microtubule-binding domain of tau protein are typically phosphorylated. ${ }^{7-8}$ Abnormal tau phosphorylation by GSK3 $\beta$ undermines the healthy dynamics of tau protein with microtubules. Overactive GSK3 $\beta$ plays a central role in $\mathrm{AD}$ pathology, causing neurodegeneration, inflammatory response, toxic $\mathrm{A} \beta$ production as well as synaptic deficit. ${ }^{8}$ Therefore, development of GSK3 $\beta$ inhibitors attenuating tau hyperphosphorylation is a promising therapeutic strategy for $\mathrm{AD}$ treatment. ${ }^{9-10}$

Corn silks (CS) of the food crop maize (Zea mays L.) have been an alternative medicine widely adopted by the Asia-Pacific cultures for the treatment of hyperglycemia, hyperlipidemia, cystitis, prostate disorder and urinary infection. ${ }^{11}$ Studies have shown that 
CS extracts are a phytotherapeutic agent with antibiotic, anti-oxidative, anti-inflammatory, anti-diabetic, and anticancer activities. ${ }^{12-15}$ Owing to the diverse bioactivities, CS metabolites are of interest to natural product and agricultural chemists. Phytochemical and metabolomic studies revealed that CS is rich in flavonoids, polysaccharides, terpenoids, and steroids. Among them, flavones are particularly abundant and characteristic in maize crops. 11,16 It has been proposed that the unique biological properties of CS such as antibiotic, anti-inflammatory and anticancer effects are mainly associated with these flavones. However, there are fewer studies of systematic evaluations of CS-derived flavones for nutraceutical and pharmaceutical applications.

As part of our efforts to look for AD phytopharmaceuticals, we utilized a kinase assay to screen GSK3 $\beta$ and CDK5/p25 inhibitors. Both GSK3 $\beta$ and CDK5/p25 have been implicated in tau hyperphosphorylation. ${ }^{7}$ Interestingly, an extract of CS selectively inhibited GSK3 $\beta$ but not CDK5/p25. Successive bioassay-guided fractionation of this CS extract afforded two known 6-C-glycosylflavones, isoorientin (1) and 3'-methoxymaysin (2). In addition to in silico studies, in vitro enzymatic assays demonstrated an ATP noncompetitive but substrate competitive inhibition by $\mathbf{1}$ and $\mathbf{2}$ specific to GSK3 $\beta$. A whole-cell lysate assay further confirmed that $\mathbf{1}$ effectively inhibited tau hyperphosphorylation mediated by GSK3 $\beta$ in vitro.

$\mathrm{A} \beta$ induces tau hyperphosphorylation and neurotoxicity in human neuroblastoma SH-SY5Y cells, which is a common cell model for AD research. ${ }^{17-19}$ While this cellular system remains limited to represent in vivo neuropathology of $\mathrm{AD}$, the inductive effects of exogenous $\mathrm{A} \beta$ on SH-SY5Y cells make it possible to study therapeutic interventions involving AD-mimic pathways. ${ }^{19-21}$ By implementing this in vitro model, immunoblot and cell viability analyses indicated that $\mathbf{1}$ and $\mathbf{2}$ are nontoxic agents, but inhibit cellular GSK3 $\beta$, and prevent tau hyperphosphorylation and neuronal cytotoxicity from amyloid insult in SHSY5Y cells.
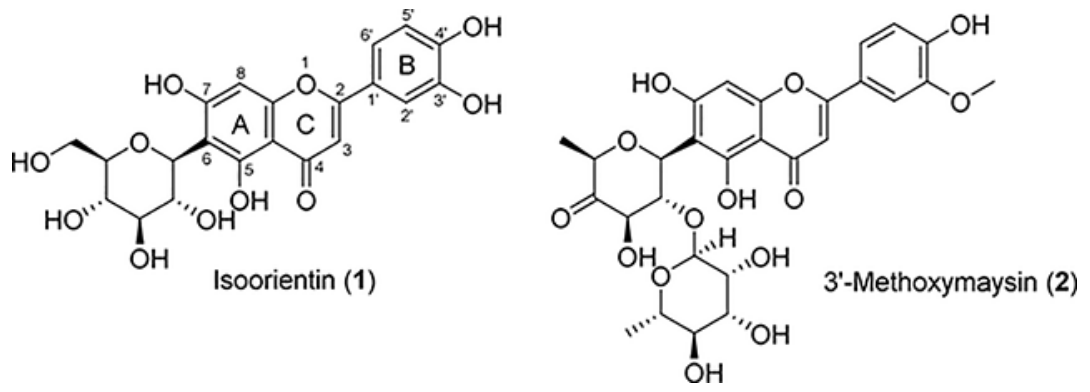

\section{RESULTS AND DISCUSSION}

\section{Isolation and Identification of GSK3 $\beta$ Inhibitory Compounds from Corn Silks}

We recently utilized an in vitro universal luminescence-based kinase assay to screen potential GSK3 $\beta$ and CDK5/p25 inhibitors. In this assay, ADP generated from a kinase reaction is chemically converted to ATP, which then couples with luciferase, such that the intensity of signal from the luciferase reaction is proportional to kinase activity. Kinase inhibitors were isolated from CS extracts via the bioassay-guided fractionation (Figure 1). 
The resulting ethyl acetate (EtOAc) fraction (CS-EA) showed plausible inhibition of GSK3 $\beta$ activity, giving a $42.7 \%$ inhibition at a concentration of $100 \mu \mathrm{g} / \mathrm{mL}$ (Table 1). In contrast, no significant inhibition against CDK5/p25 was observed with this fraction at the same concentration (data not shown). LC-QTOF-MS profiling revealed that the EtOAc fraction contained a series of compounds with molecular weights between 480 and $600 \mathrm{amu}$ along with UV maxima at 260 and $350 \mathrm{~nm}$, suggesting the presence of glycosidic flavones. ${ }^{12}$ Further bioassay-guided fractionation and HPLC purification of this EtOAc fraction led to the isolation of two 6- $C$-glycosylflavones, $\mathbf{1}$ and $\mathbf{2}$ in over $95 \%$ purity as determined by HPLC-UV at $205 \mathrm{~nm}$. Chemical identity of $\mathbf{1}$ and $\mathbf{2}$ was determined by NMR spectroscopic comparison with reported data ${ }^{22-23}$ in conjunction with ESI-CID-MS/MS analyses. ${ }^{24}$ The ESI-QTOF-CID-MS/MS analysis of 2 showed an ion at $\mathrm{m} / \mathrm{z} 445.1136$ corresponding to $\left[\mathrm{Y}_{1}\right]^{+}$, confirming the presence of a rhamnose, while the observed ion $\left[{ }^{0,2} \mathrm{~B}\right]^{+}$at $\mathrm{m} / \mathrm{Z}$ 150.6861 indicated a methoxy group at the B-ring of $\mathbf{2}$ (Figure S1). 1 and $\mathbf{2}$ showed moderate GSK3 $\beta$ inhibition with an $\mathrm{IC}_{50}$ value of 185 and $288 \mu \mathrm{M}$, respectively, whereas they were inactive against $\mathrm{CDK} 5 / \mathrm{p} 25\left(\mathrm{IC}_{50}>15 \mathrm{mM}\right)$ (Figure 2A).

Flavonoids have been reported as potential colloidal aggregators showing promiscuous inhibition of proteins. ${ }^{25}$ These promiscuous inhibitors aggregate with proteins nonspecifically and promote protein unfolding, which is a common cause of false positives in high-throughput screenings. To investigate if the GSK3 $\beta$ inhibition of $\mathbf{1}$ was due to this undesired mechanism, $\mathbf{1}$ was assayed against GSK3 $\beta$ in a kinase buffer containing varying concentrations of Triton X-100 to disrupt possible aggregation. ${ }^{26}$ Intriguingly, GSK3 $\beta$ inhibition was insensitive to the addition of detergent as the resulting $\mathrm{IC}_{50}$ value of $\mathbf{1}$ did not significantly change (with $0.01 \%$ Triton, $\mathrm{IC}_{50}, 192 \mu \mathrm{M}$ ) (Figure S2). This observation was consistent with the inhibitory behavior of staurosporine, a well-known GSK3 $\beta$ inhibitor without aggregation (with $0.01 \%$ Triton, $\mathrm{IC}_{50}, 3 \mathrm{nM}$ ). Conversely, luteolin, a flavone showing GSK $3 \beta$ inhibition but promoting aggregation, ${ }^{25}$ decreased the potency by 16 -fold with the addition of $0.01 \%$ Triton (increased $\mathrm{IC}_{50}$ value from 2 to $32 \mu \mathrm{M}$ ). Structurally, luteolin is the flavone core of $\mathbf{1}$ without $C$-glycone. The behavioral difference between luteolin and $\mathbf{1}$ in the promiscuous inhibition assay suggested that the $C$-glycosyl group of $\mathbf{1}$ plays an essential role in GSK3 $\beta$ inhibition. Since ruling out the possibility of promiscuous inhibition, further biological evaluations proceeded with the stronger GSK3 $\beta$ inhibitor 1.

\section{Isoorientin Selectively Inhibits GSK3 $\beta$ in an ATP Noncompetitive Mechanism}

To further evaluate the kinase inhibitory selectivity, $\mathbf{1}$ was assayed on a broad panel of 22 kinases relevant to $\mathrm{AD}$, using the universal kinase assay system. As shown in Figure 2B, 1 effectively inhibited GSK3 $\beta$ (decreased $52.4 \%$ kinase activity, $p<0.0001$ ) in vitro at a concentration of $224 \mu \mathrm{M}$ compared to the control (100\% kinase activity). It is interesting that 1 did not significantly inhibit other 18 kinases $(p>0.05)$ except AKT1, PKC and CK2. Although 1 also showed approximately $30 \%$ inhibition against AKT1, PKC and CK2, inhibitory selectivity of GSK3 $\beta$ was the most distinct in this study. Aside from GSK3 $\beta$ it has been reported that CDK5, ERK2, JNK, p38, PKA, AKT, PKC, CAMKII, DAPK, AMPK, and $\mathrm{CK} 1 / 2$ contribute positively to tau hyperphosphorylation in human. ${ }^{7}$ The exceptional selectivity of $\mathbf{1}$ to GSK3$\beta$ over the other AD relevant kinases suggested that 1 interacts with GSK3 $\beta$ at an allosteric domain rather than the common conserved ATP-binding pocket. 
Enzyme kinetic experiments were then performed to elucidate the underlying mechanism of 1 on GSK3 $\beta$ inhibition. As illustrated in Figure 2C, when concentrations of the GSK3 $\beta$ substrate GS2 (peptide YRRAAVPPSPSLSRHSSPHQ(pS)EDEEE, derived from human muscle glycogen synthase) were held constant at $17 \mu \mathrm{M}$, velocities of ATP-ADP conversion at a given concentration of $\mathbf{1}$ were measured over a period of time. Michealis-Menten kinetic analysis indicated that 1 reduced GSK3 $\beta$ activity (decreased $V_{\max }$ ) with an increase of concentration of $\mathbf{1}$ but not compete with ATP at the active site of GSK3 $\beta$, for which it remained an unaltered Michaelis constant $\left(K_{\mathrm{m}}, 76 \mu \mathrm{M}\right)$. Moreover, a Dixon plot of enzyme kinetics showed a convergence of intersecting lines on horizontal axis that further corroborated the ATP noncompetitive mechanism of $\mathbf{1}$ with a $K_{\mathrm{i}}$ value of $210 \mu \mathrm{M}$ (Figure 2D).

GSK3 $\beta$ is a proline-directed serine/threonine kinase ubiquitously expressed in mammals. It plays a pivotal role in regulating various processes of cell signal transduction including glycogen metabolism, gene transcription, protein translation, cytoskeletal stabilization, cell development and apoptosis. In particular, GSK3 $\beta$ is a key regulator mediating neural development in human. ${ }^{27}$ The normal state of GSK $3 \beta$ regulates the healthy functioning of neurons, whereas elevated activity of GSK3 $\beta$ is implicated in AD pathology. ${ }^{7-8}$ Inhibiting levels of GSK $3 \beta$ in an aberrant state is a promising therapeutic strategy for AD treatment. To date, the majority of inhibitors has targeted the highly conserved ATP-binding cavity on GSK $3 \beta . .^{9}$ Although GSK3 $\beta$ inhibitors targeting this active site could achieve high potency, the limited selectivity of ATP competitive inhibitors raises concerns about the safety and tolerability of this class of molecules, which remains a major hurdle in AD drug development. ${ }^{10}$ Alternatively, seeking ATP noncompetitive inhibitors is a feasible approach to improve inhibitory selectivity, because these inhibitors tend to bind to uniquely folded domains within GSK3 $\beta$ instead of simply blocking ATP entrance. ${ }^{28}$ In addition, since GSK3 $\beta$ regulates essential cell signaling events, moderate-to-weak inhibition of aberrant GSK $3 \beta$ activity may actually normalize GSK3 $\beta$ functions. ${ }^{29}$ The efficacy of many ATP noncompetitive GSK3 $\beta$ inhibitors of synthetic and natural origins has been demonstrated in a variety of cellular and animal models. Two of them, Tideglusib (a TDZD compound) and lithium ion, have advanced to Phase II clinical trials, which offers a promising prospect. ${ }^{29}$ In the present study, because maize is a food crop, it is conceivable that $\mathbf{1}$ along with its CSderived $C$-glycosidic flavones, acting as ATP noncompetitive inhibitors of GSK3 $\beta$, are safe agents worthy of advanced biological studies.

\section{Isoorientin Exerts Allosteric Inhibition of GSK3 $\beta$ in a Substrate Competitive Mode}

Owing to the aforementioned drawbacks of ATP competitive inhibitors of GSK3 $\beta$, new ATP noncompetitive inhibitors with increased selectivity are of high interest in the development of AD pharmaceuticals targeting tauopathy. Comprehensive mapping and identification of the binding sites of GSK3 $\beta$ by computational simulations has allowed for a better elaboration and evaluation of allosteric kinase inhibitors. ${ }^{28}$ For example, some complex small-molecules, such as manzamine $\mathrm{A}^{30}$ and peptide $\mathrm{L} 803,{ }^{29}$ have been validated as ATP noncompetitive inhibitors with the assistance of molecular modeling. 
The interaction of $\mathbf{1}$ with GSK3$\beta$ was therefore examined by computational simulation using the X-ray crystallographic structures of GSK3 $\beta$ (PDB code 1PYX and 1Q3D). Protein and ligand structures were prepared as described prior to docking. Using these parameters, the ligand staurosporine, a known ATP competitive inhibitor, was successfully re-docked into the active ATP-binding site of GSK3 $\beta$, with a RMSD of $0.93 \AA$ compared to its original crystal structure $^{31}$ (Figure $3 \mathrm{~A}$ and B). Simulation under the same condition revealed that 1 resides within the substrate-binding site of GSK3 $\beta$, an allosteric cavity immediately near to the ATP-binding pocket (Figure 3C). The $C$-glycone of 1 makes polar interactions with GSK3 $\beta$ residues Leu88, Gln89, Asp90, Lys94 and Arg96 within the substrate-binding pocket to form hydrogen bonds. The aromatic flavone core of $\mathbf{1}$ shows hydrophobic interactions with residues Phe67 and Val87, and the 7-hydroxyl oxygen atom at the A-ring of the flavone core shows a hydrogen bond with residue Asn95. In conjunction, interactions of the 3'-hydroxyl oxygen atom at the B-ring of the flavone core with the two $\mathrm{Mg}^{2+}$ ions in the magnesium-binding site of GSK3 $\beta$ potentially stabilize these binding interactions. The role of $\mathrm{Mg}^{2+}$ cofactors is known to be essential for the GSK3 $\beta$ kinase reaction as they assist the key steps in ATP phosphoryl transfer. Competitive replacement of magnesium by lithium significantly inhibits GSK3 $\beta$ activity. ${ }^{32}$ In the present study, interactions of 1 with $\mathrm{Mg}^{2+}$ may weaken the binding affinity of ATP with GSK3 $\beta$. Furthermore, residues Phe67, Gln89 and Asn95 within the substrate-binding site of GSK3$\beta$ are particularly crucial for substrate recognition as mutating any of these amino acids causes the loss of kinase activity. ${ }^{33}$ The docking results indicated that interactions of $\mathbf{1}$ with these key residues in the substratebinding site of GSK3 $\beta$ may partially explain its inhibitory action and selectivity $\left(\mathrm{IC}_{50}, 185\right.$ $\mu \mathrm{M})$. In comparison, $2\left(\mathrm{IC}_{50}, 288 \mu \mathrm{M}\right)$ shows less favorable interactions with Phe67, Gln89 and Asn95, probably due to steric hindrance from the larger $C$-glycone (Figure 3D). Structural features of both flavone and glycone in $\mathbf{1}$ favor specific interactions with the substrate-binding pocket of GSK3 $\beta$, whereas luteolin without $C$-glycone showed nonspecific inhibition of SK3 $\beta$ (Figure S2). The $C$-glycosidic moiety putatively acts as a key structural element in $\mathbf{1}$ for GSK3 $\beta$ specific inhibition and selectivity.

To validate the molecular docking results, we conducted kinetic experiments of GSK3 $\beta$ when ATP concentrations were fixed at $25 \mu \mathrm{M}$. At a given concentration of 1 , rates of ATP conversion were plotted versus different concentrations of substrate GS2. In this case, Michealis-Menten kinetics and corresponding Dixon plot clearly showed a competitive inhibition mode between GS2 and 1 with a $K_{\mathrm{i}}$ value of $125 \mu \mathrm{M}$ (Figure 3E and F), indicating that 1 interacts with the substrate-binding site of GSK3 $\beta$ as predicted from the docking postulation. Taken together, the enzymological experiments in silico and in vitro supported an ATP noncompetitive inhibition mechanism by which 1 inhibits GSK3 $\beta$ via allosteric interactions within the substrate-binding pocket.

\section{Isoorientin Inhibits GSK3 $\beta$-Mediated Tau Hyperphosphorylation in a Whole-Cell Lysate Kinase Assay}

Given our hypothesis that $\mathbf{1}$, being an ATP noncompetitive inhibitor of GSK3 $\beta$, can alleviate tau hyperphosphorylation, we investigated the potential of $\mathbf{1}$ against GSK3 $\beta$-mediated tau phosphorylation. To determine whether the intervention of $\mathbf{1}$ on tau phosphorylation is ascribed to a direct GSK3 $\beta$ inhibition in an ex vivo matrix, we designed a simple in vitro 
GSK3 $\beta$ assay to take advantage of a whole-cell lysate of the neuroblastoma SH-SY5Y cells. In this assay, an aliquot of lysate was fortified with exogenous GSK3 $\beta$ (wt/wt $0.25 \%$ ), and incubated with $\mathbf{1}(112 \mu \mathrm{M})$ or $\mathrm{LiCl}(10 \mathrm{mM})$ for $2 \mathrm{~h}$, followed by western blotting probed with anti-tau pS199/pS202 and pS396 antibodies. Tau-5 and GSK3 $\beta$ antibodies were also applied to assess the respective total protein levels. It has been reported that phosphorylation sites pS199/pS202 and pS396 on tau are GSK3 $\beta$ specific. ${ }^{6}$ Abnormal tau phosphorylation at these sites impairs microtubule stabilization and neurite outgrowth, which is closely linked to $\mathrm{AD} .^{6,34}$ Western blot results substantiated that overactive GSK3 $\beta$ by introducing exogenous GSK3 $\beta$ significantly increased tau phosphorylation at sites pS199/pS202 and pS396 approximately three fold $(p<0.0001)$ in comparison to their basal phosphorylation levels (lysate spiked with heat-inactivated GSK3 $\beta$ ) (Figure 4). Conversely, treatment of $\mathbf{1}$ or $\mathrm{LiCl}$ showed an apparent attenuation on tau phosphorylation for those specific sites mediated by GSK3 $\beta$ ( $p<0.01$ ). Noticeably, the anti-tau phosphorylation potency of $\mathbf{1}$ at 112 $\mu \mathrm{M}$ was comparable to that of $\mathrm{LiCl}$ at $10 \mathrm{mM}$, which the latter is a weak but specific GSK3 $\beta$ inhibitor $\left(\mathrm{IC}_{50}, 2 \mathrm{mM}\right)$ currently in clinical trials for $\mathrm{AD}$. The encouraging data from the whole-cell lysate kinase assay provided plausible evidence of GSK3 $\beta$ inhibition and its subsequent effect on GSK3 $\beta$-mediated tau hyperphosphorylation upon treatment with $\mathbf{1}$.

\section{Isoorientin Attenuates A $\beta$-Induced Tau Hyperphosphorylation in SH-SY5Y Cells}

Although in vitro enzymological studies demonstrated the potential of 1 for GSK3 $\beta$ inhibition and anti-tau phosphorylation, additional validations for those effects within a cellular level remain necessary. Growing evidence indicated that A $\beta$ activates GSK3 $\beta$ via PI3K/AKT/GSK3 $\beta$ signaling in AD, thereby causing downstream tau hyperphosphorylation in neurons. ${ }^{8,} 35$ We examined the alleviative effects of $\mathbf{1}$ on tau hyperphosphorylation in a cell model relevant to $A D$ pathology, in which the cells were administrated with $A \beta_{42}$. Human neuroblastoma SH-SY5Y cells were used in this research as they possess the functionality and molecular features resembling to human neurons. ${ }^{18-19}$ Cellular phosphorylation levels were assessed with antibodies against pS199/pS202 and pS396 on tau protein, while the extent of an inactive form of GSK3 $\beta$ (phosphorylated GSK3 $\beta$ at Ser9) with antibody GSK3 $\beta$ pS9. Those abnormal phosphorylations have been found in AD. ${ }^{6,8}$ Tau-5 and GSK3 $\beta$ antibodies were used to evaluate the respective total protein expressions.

Figure 5 shows that treatment of SH-SY5Y cells with $10 \mu \mathrm{M} \mathrm{A} \beta_{42}$ for $72 \mathrm{~h}$ increased tau phosphorylation at sites pS199/pS202 and pS396 approximately 3.5 and 2.3 fold, respectively, relative to untreated cells. In contrast, pretreatment of $\mathbf{1}$ at varying concentrations $(28,112$ and $448 \mu \mathrm{M})$ to SH-SY5Y cells for $1 \mathrm{~h}$ followed by co-incubation with $10 \mu \mathrm{M} \mathrm{A} \beta_{42}$ for $72 \mathrm{~h}$ significantly decreased tau phosphorylation levels at all phosphorylation sites in a dose-dependent manner $(p<0.01)$ (Figure 5B). Significant alleviative effects of $\mathbf{1}$ on tau phosphorylation were achieved even at lower doses (e.g., 28 $\mu \mathrm{M})$.

No significant change was observed in levels of both GSK3 $\beta$ pS9 and total GSK3 $\beta$ in the cells upon treatments (either $A \beta_{42}$ treatment alone or co-incubation of 1 with $A \beta_{42}$ ) compared to untreated cells $(p>0.05)$ (Figure 5A and C). A downregulating effect of $A \beta$, in particular the $A \beta_{25-35}$ fragment, on an inactive form of GSK3 $\beta$ has been postulated to 
account for GSK3 $\beta$ activation in certain cell models. ${ }^{36-37}$ The results of the present study, however, showed no apparent changes on GSK3 $\beta$ pS9 levels upon treatments, suggesting complexity in GSK3 $\beta$ activation. While the exact mechanism between $A \beta_{42}$ stimuli and GSK3 $\beta$ activation in SH-SY5Y cells is still unclear, the consequential effect of $\mathbf{1}$ on anti-tau phosphorylation is putatively from a direct inhibition of GSK3 $\beta$ in the cells (Figure 5).

GSK3 $\beta$ inhibition and anti-tau phosphorylation of 1 were further experimentally supported by co-treatment of 1 with GSK3 $\beta$ specific inhibitors in A $\beta_{42}$ treated SH-SY5Y cells. LiCl $\left(\mathrm{IC}_{50}, 2 \mathrm{mM}\right)$ and TDZD-8 $\left(\mathrm{IC}_{50}, 2 \mu \mathrm{M}\right)$ are GSK3 $\beta$ specific inhibitors and have shown a promise for AD treatment. ${ }^{29}$ We therefore used them as references to compare effects of $\mathbf{1}$ on anti-tau hyperphosphorylation in the cells. As depicted in Figure 6A, brief pretreatment of $1(112 \mu \mathrm{M}), \mathrm{LiCl}(10 \mathrm{mM})$ or TDZD-8 $(10 \mu \mathrm{M})$ to SH-SY5Y cells for $1 \mathrm{~h}$ followed by coincubation with $10 \mu \mathrm{M} \mathrm{A} \beta_{42}$ for $72 \mathrm{~h}$ displayed an expected decrease of tau phosphorylation at sites pS199/pS202 and pS396 ( $p<0.001)$. Notably, when co-treatment of $\mathbf{1}(112 \mu \mathrm{M})$ with $\mathrm{LiCl}(10 \mathrm{mM})$ to SH-SY5Y cells for $1 \mathrm{~h}$ followed by co-incubation with $10 \mu \mathrm{M} \mathrm{A} \beta_{42}$ for 72 $\mathrm{h}$, an effect against tau phosphorylation for sites pS199/pS202 and pS396 was enhanced in comparison with either $\mathbf{1}$ or $\mathrm{LiCl}$ individual treatment (Figure 6B). Co-treatment of $\mathbf{1}$ with $\mathrm{LiCl}$ could result in a synergistic effect on anti-tau phosphorylation due to their distinct mechanisms of GSK3 $\beta$ inhibition - substrate competition by $\mathbf{1}$ and $\mathrm{Mg}^{2+}$ displacement by $\mathrm{Li}$ + . On the other hand, TDZD-8 $(10 \mu \mathrm{M})$ co-treated with $1(112 \mu \mathrm{M})$ did not change the level of anti-tau phosphorylation in comparison with TDZD-8 alone $(p>0.05)$. This phenomenon can be plausibly explained by the fact that TDZDs are ATP noncompetitive and irreversible inhibitors of GSK $3 \beta .{ }^{38}$ While X-ray crystallographic structures of GSK3 $\beta$ with TDZDs were not available, computational simulation suggested that TDZDs appear to interact within the substrate-binding site of GSK3 $\beta .{ }^{39}$ It is possible that the more potent and irreversible inhibitor TDZD-8 ( $\mathrm{IC}_{50}, 2 \mu \mathrm{M}$ ) overperformed $\mathbf{1}$ during co-treatment (Figure 6A and B). Upon those treatments, little changes in the levels of GSK3 $\beta$ pS9 and total GSK3 $\beta$ were observed by western blot analyses $(p>0.05)$ (Figure 6C). Nonetheless, the similarity of pharmacological phenomena between $\mathbf{1}$ and the known GSK3 $\beta$ specific inhibitors, in conjunction with the findings in the whole-cell lysate kinase assay, indeed conferred that $\mathbf{1}$ is an effective GSK3 $\beta$ inhibitor attenuating aberrant tau phosphorylation in the human cells.

\section{Isoorientin Exerts Neuroprotection against A $\beta$-Induced Cytotoxicity in SH-SY5Y Cells}

Finally, we investigated whether 1 exerts neuroprotective effects against A $\beta$-induced cytotoxicity in human SH-SY5Y cells. Oligomers of $A \beta_{42}$ can activate GSK3 $\beta$, resulting in tau hyperphosphorylation and microtubule disassembly within axons of neuron. ${ }^{34}$ This neurotoxic effect of $A \beta_{42}$ could consequently lead to the axonal and dendritic impairment followed by neuron cell death. ${ }^{40}$ Such toxic effects were substantiated by a dramatic cell viability reduction after the addition of $A \beta_{42}$ oligomers in SH-SY5Y cells (Figure 7A). Since $\mathrm{A} \beta_{42}$ at $10 \mu \mathrm{M}$ inhibited about $50 \%$ cell growth in vitro based on cell viability assay, this dose was used in the subsequent experiments. Pretreatment of SH-SY5Y cells with 1 $(112 \mu \mathrm{M})$ for $1 \mathrm{~h}$ followed by co-incubation with $10 \mu \mathrm{M} \mathrm{A} \beta_{42}$ for $72 \mathrm{~h}$ resulted in a neuroprotection against cell viability loss, whose effect was similar to the known GSK3 $\beta$ inhibitors LiCl and TDZD-8 (Figure 7B). Interestingly, co-treatment of $\mathbf{1}(112 \mu \mathrm{M})$ with $\mathrm{LiCl}(10 \mathrm{mM})$ showed a synergistic neuroprotection, whereas co-treatment with TDZD-8 
$(10 \mu \mathrm{M})$ did not (Figure 7B). Quantitative dose-response measurement of cell viability demonstrated effective inhibitions of 1 to neurotoxic induction by $10 \mu \mathrm{M} \mathrm{A} \beta_{42}$ with an $\mathrm{EC}_{50}$ value of $47 \mu \mathrm{M}$ (Figure 7C and D). Remarkably, no cytotoxicity of $\mathbf{1}$ to SH-SY5Y cells was noted up to a dose of $896 \mu \mathrm{M}$ (Figure 7E). Instead, the data showed that 1 slightly stimulated cell proliferation. This result suggested that $\mathbf{1}$ exhibited a good safety margin and tolerability profile. In addition, microscopic observations illustrated apparent neuronal morphological changes of SH-SY5Y cells upon $10 \mu \mathrm{M} \mathrm{A} \beta_{42}$ treatment, particularly the substantial retraction of axons and dendrites (Figure $8 \mathrm{~A}$ and $\mathrm{B}$ ). In contrast, treatment of $\mathbf{1}$ effectively prevented the differentiated SH-SY5Y cells from A $\beta_{42}$ intoxication as a large number of healthy cells with extended axons and dendrites were observed (Figure 8C and D). These observations together with the cell viability analysis suggested that $\mathbf{1}$ exhibits effective antiA $\beta$ neurotoxicity through protecting cell differentiation and neurite extension, whose functions are highly regulated by tau proteins in neuron.

To further verify that $C$-glycosylflavones in the CS extracts are contributive to neuroprotection, we assayed CS fractions on anti-A $\beta$ neurotoxicity. Those fractions active in the GSK3 $\beta$ assay indeed displayed proportional effects in defense of A $\beta$-induced cytotoxicity in SH-SY5Y cells (Figure S3). Interestingly, 2, the less potent GSK3 $\beta$ inhibitor, exerted neuroprotection but with a weaker potency compared to $\mathbf{1}\left(\mathrm{EC}_{50}, 154 \mu \mathrm{M}\right)$.

6- $C$-glycosylflavones are a major class of flavones produced in CS via the maysin biosynthetic pathway. ${ }^{41}$ These endogenous flavones are well known for their unique activities against corn earworms. ${ }^{12,41}$ While these $C$-glycosylflavones have originally evolved in maize plant for chemical defense purposes, it has been postulated that this class of metabolites can exert biological effects on therapeutic targets such as AD-relevant kinases in human on the basis of their chemical characteristics. ${ }^{42-43}$ With respect to the chemical structure of $C$-glycosylflavones, the presence of carbon-linked glycosidic bond makes these compounds more resistant to metabolic hydrolysis, which is distinct from the $O$ glycosylflavones prevalent in flora. Interestingly, studies reported that CS-derived flavones show neuroprotective activities by inhibiting cholinesterases ${ }^{44}$ and reactive oxygen species 45 in different enzyme-based or cell-based models. It is also reported that $\mathbf{1}$ exerts anticancer activity by intervening the PI3K/AKT signaling in human HepG 2 cells, ${ }^{46-47}$ which the pathway is highly associated with neuronal survival relevant to AD. ${ }^{35} \mathrm{CS}$-derived flavones including 1 may potentiate a synergistic effect by leveraging multi-activities to gain a maximal neuroprotective profile to tackle AD. Among those activities, anti-tau hyperphosphorylation through GSK $3 \beta$ inhibition by $\mathbf{1}$ is a key contributor, as supported by the results of the present study.

Flavones are known for their multi-functional actions. ${ }^{42-43}$ It has become evident that flavones exerting their neuroprotection are probably due to the interaction with key cellular receptors or enzymes that regulate neuronal apoptosis, survival, differentiation and proliferation. ${ }^{42,48} \mathrm{AD}$ is a complex neurodegeneration involving $\mathrm{A} \beta$ neurotoxicity, tau hyperphosphorylation, $\mathrm{Ca}^{2+}$ dysregulation, oxidative stress production, neuroinflammation, and synaptic dysfunction. ${ }^{2}$ An anti-AD agent modulating multiple targets and signaling pathways in a disease-relevant context can offer valuable properties in pharmaceutical applications. In the present study, because $A \beta_{42}$ triggers neurotoxicity through complex 
pathways in SH-SY5Y cells, the polypharmacological concept ${ }^{49-50}$ may explain the slight discrepancy that $\mathbf{1}$ is more potent in the cellular assay $\left(\mathrm{EC}_{50}, 47 \mu \mathrm{M}\right)$ than in the GSK3 $\beta$ assay $\left(K_{\mathrm{i}}, 125 \mu \mathrm{M}\right)$. While 1 showed selective inhibition to GSK3 $\beta$ among 22 AD-relevant kinases tested, its potential action on multi-targets may be favorable in AD therapies. $C$ glycosylflavones warrant further investigation as $\mathrm{AD}$ phytopharmaceuticals.

\section{CONCLUSION}

As of today, four drugs have been approved by the US FDA for AD treatment, while one has been approved by the Chinese FDA. All of them only alleviate short-term cognitive symptoms. ${ }^{9}$ There is a critical demand for new agents with greater efficacy and safety to slow, halt, prevent and ideally reverse $\mathrm{AD}$. The present study emphasized a tau-targeted therapeutic strategy to remedy AD. We screened phytochemicals for potential inhibition of AD-relevant kinases. A tandem approach of bioassay-guided fractionation and LC-MS analysis of CS extracts afforded two 6- $C$-glycosylflavones (1 and $\mathbf{2}$ ) as GSK3 $\beta$ inhibitors. Isoorientin (1) showed moderate potency but notable selectivity and specificity in the kinase assay profile system. In vitro enzymatic and cellular evaluations as well as in silico molecular modeling revealed a putative mechanism of action by which $\mathbf{1}$ involves in blocking GSK3 $\beta$ via an ATP noncompetitive inhibition to attenuate tau hyperphosphorylation. The results demonstrated the first time that CS-derived $C$ glycosylflavones are ATP noncompetitive inhibitors of GSK3 $\beta$. 1 also exerts effective neuroprotection against A $\beta$-induced cytotoxicity in the human SH-SY5Y cell model, which is plausibly involved in the tau-dependent pathway. $\mathbf{1}$ can be a potential lead candidate with a good safety margin for AD prevention and treatment. Nevertheless, SAR-based development remains necessary to achieve a better efficacy, bioavailability and blood-brain barrier permeability of $C$-glycosyl flavonoids. Further assessments of $\mathbf{1}$ and its analogues in $\mathrm{AD}$ animal models must be conducted in order to validate their in vivo effectiveness for toxic tau clearance as well as the cognitive benefits.

\section{METHODS}

\section{Chemicals and Reagents}

Staurosporine, 4-benzyl-2-methyl-1,2,4-thiadiazolidine-3,5-dione (TDZD-8), lithium chloride ( $\mathrm{LiCl}$ ), luteolin, Triton X-100, protease inhibitor cocktail, and 5-bromo-4-chloro-3indolyl-phosphate/nitro blue tetrazolium (BCIP/NBT) reagents were from Sigma-Aldrich (Saint Louis, MO, USA). $\beta$-Amyloid fragment peptide 1-42 (A $\left.\beta_{42}\right)$ was from AnaSpec (Fremont, CA, USA). Kinase Selectivity Profiling Assay Kit, ADP-Glo Kinase Assay Kit, and CellTiter 96 AQueous One Solution Cell Proliferation MTX Assay Kit were from Promega (Madison, WI, USA). Antibodies Tau-5, Tau pS199/pS202, Tau pS396, GSK3 $\beta$, and GSK3 $\beta$ pS9 were from Invitrogen (Camarillo, CA, USA). $\beta$-Actin antibody was from GenScript (Piscataway, NJ, USA). Alkaline phosphatase-conjugated secondary antibodies were from Southern Biotech (Birmingham, AL, USA). 


\section{General Experimental Procedures}

High-resolution mass spectrometric data were obtained on a Bruker maXis Impact nanoLCQTOF-MS spectrometer in ESI mode. Luminescent measurement was performed on an Agilent Cary Eclipse fluorescence spectrophotometer. Optical absorbance was measured on a Multiskan GO Microplate spectrophotometer. ${ }^{1} \mathrm{H},{ }^{13} \mathrm{C}$ and 2D NMR data were recorded with a Varian Unity Inova $500 \mathrm{MHz}$ spectrometer. NMR spectra were referenced to the appropriate residual solvent signal $\left(\delta_{\mathrm{H}} 2.50, \delta_{\mathrm{C}} 39.5\right.$ for DMSO- $\left.d_{6}\right)$ with chemical shifts reported in $\delta$ units (ppm). Microscopic images were observed under a Nikon Diaphot inverted tissue culture microscope with Optronics MicroFire microscope camera.

\section{Collection}

Fresh corn silks (CS, Zea mays L.) were collected from the Waimanalo Research Station, University of Hawaii at Manoa, USA. Upon collection, fresh CS sample was immediately lyophilized and stored at $-20^{\circ} \mathrm{C}$ until extraction.

\section{Extraction and Isolation}

A modified protocol of the bioassay-guided fractionation was used. ${ }^{51} \mathrm{~A} 90 \mathrm{~g}$ portion of lyophilized CS sample was exhaustively extracted with $1000 \mathrm{~mL}(\times 5)$ of $\mathrm{CH}_{2} \mathrm{Cl}_{2}: \mathrm{MeOH}$ ( $\mathrm{v} / \mathrm{v} 2: 1)$ to yield $45 \mathrm{~g}$ of crude extract. This crude extract was subject to successive solvent partitioning using a modified Kupchan method with $n$-hexane, ethyl acetate (EtOAc), $n$ butanol and $\mathrm{H}_{2} \mathrm{O}$ to yield four fractions of 3.7, 0.9, 4.8 and $34.7 \mathrm{~g}$, respectively. The EtOAc fraction $(0.9 \mathrm{~g})$ was further subject to flash column chromatography on a DPA-6S polyamide column $(50 \mathrm{~g})$ using a step gradient of $25(\times 2), 50(\times 2), 75(\times 2)$ and $100 \%(\times 2) \mathrm{MeOH}$ in $\mathrm{H}_{2} \mathrm{O}$, affording eight fractions (A-H) of 230.5, 80.0, 40.2, 50.8, 30.5, 70.6, 70.1 and 90.5 $\mathrm{mg}$. GSK3 $\beta$ assay data indicated that the kinase inhibitory activity was concentrated in fraction F (70.6 mg). Separation of fraction F on a reversed-phase HPLC [CSH FluoroPhenyl, $150 \times 4.6 \mathrm{~mm}$, a linear gradient over $40 \mathrm{~min}$ from 10 to $50 \%$ acetonitrile in $\mathrm{H}_{2} \mathrm{O}$ solvents, flow rate $0.7 \mathrm{~mL} / \mathrm{min}$, PDA detection] afforded five subfractions, whose GSK3 $\beta$ inhibitory activities were concentrated in subfraction-2 (CS-EA-F-2; $3.1 \mathrm{mg}$ ) and subfraction-3 (CS-EA-F-3; $5.4 \mathrm{mg}$ ). Further purification of these two subfractions under the same conditions led to the isolation of $\mathbf{1}\left(t_{\mathrm{R}} 17.5 \mathrm{~min}, 2.5 \mathrm{mg}, 0.006 \%\right.$ yield $)$ and $\mathbf{2}\left(t_{\mathrm{R}} 23.1\right.$ min, $1.2 \mathrm{mg}, 0.003 \%$ yield) in over 95\% purity as determined by HPLC-UV at $205 \mathrm{~nm}$. The identity of $\mathbf{1}$ and $\mathbf{2}$ was confirmed by ESI-QTOF-CID-MS/MS analysis and comparison with reported NMR spectroscopic data.

1: light yellow solid; HRESI-TOFMS $m / z[\mathrm{M}+\mathrm{H}]^{+} 449.1085$ (calcd for $\mathrm{C}_{21} \mathrm{H}_{21} \mathrm{O}_{11}{ }^{+}$, 449.1078, -1.4 ppm error).

2: light yellow solid; HRESI-TOFMS $m / z[\mathrm{M}+\mathrm{H}]^{+} 591.1711$ (calcd for $\mathrm{C}_{28} \mathrm{H}_{31} \mathrm{O}_{14}{ }^{+}$, $591.1708,-0.5$ ppm error).

\section{Kinase Luminescent Assay}

Kinase inhibition was assessed with the ADP-Glo Kinase Assay. ${ }^{52}$ For screening, $5 \mathrm{ng} / \mu \mathrm{L}$ of kinase was assayed in a reaction containing $50 \mathrm{ng} / \mu \mathrm{L}$ substrate, $40 \mathrm{mM}$ Tris, $\mathrm{pH} 7.5,20 \mathrm{mM}$ $\mathrm{MgCl}_{2}, 0.1 \mathrm{mg} / \mathrm{mL}$ bovine serum albumin (BSA), $50 \mu \mathrm{M}$ dithiothreitol (DTT), $25 \mu \mathrm{M}$ ATP, 
varying concentrations of test samples or 5\% dimethyl sulfoxide (DMSO) as vehicle. The reaction mixture was incubated for $1 \mathrm{~h}$ at room temperature followed by the addition of the ADP-Glo reagents according to the manufacturer's protocol. The kinase inhibitor staurosporine was used at $1 \mu \mathrm{M}$ as a reference control. Each data point was collected in quadruplicate of two independent experiments.

Promiscuous aggregations were assessed with the screening assay in the presence of $0 \%$, $0.001 \%, 0.01 \%$ and $0.05 \%(\mathrm{v} / \mathrm{v})$ of Triton X-100. Luteolin was used as a reference control for promiscuous inhibition.

To study the kinase kinetics, a reaction solution contained $5 \mathrm{ng} / \mu \mathrm{L}$ kinase, $40 \mathrm{mM}$ Tris, $\mathrm{pH}$ $7.5,20 \mathrm{mM} \mathrm{MgCl} 2,0.1 \mathrm{mg} / \mathrm{mL} \mathrm{BSA}, 50 \mu \mathrm{M}$ DTT, and varying concentrations of ATP or substrate versus test samples. The mixture was incubated for 5, 15, 30 and $60 \mathrm{~min}$ at room temperature followed by the addition of the ADP-Glo reagents according to the manufacturer's protocol.

\section{Molecular Modeling}

Compounds of interest were docked using the X-ray crystallographic structures of GSK3 $\beta$ (PDB code 1PYX and 1Q3D) ${ }^{31}$ and AutoDock Vina 1.1.2. ${ }^{53}$ Water molecules within the crystal structure were removed and polar hydrogens and Gasteiger charges were added using AutoDockTools. Ligands were optimized for their energy and geometry using MMFF94 and AM1 force fields prior to docking. All bonds of ligands were treated as rotatable except for the aromatic, alkenyl, carbonyl bonds and rings. The dimensions of the grid map were $30 \times$ $30 \times 30$ points with a grid-point spacing of $1 \AA$. Docking proceeded with an exhaustiveness value of 500 and a maximum output of 100 structures.

\section{Cell Culture}

Human neuroblastoma SH-SY5Y cell line (Sigma-Aldrich, Saint Louis, MO, USA) was cultured in DMEM/F12 (v/v 1:1) media supplemented with $2 \mathrm{mM}$ glutamine, $10 \%$ heatinactivated fetal bovine serum (FBS) and $1 \%$ antibiotics including penicillin and streptomycin. Cell cultures were incubated at $37{ }^{\circ} \mathrm{C}$ in a fully humidified atmosphere containing $5 \% \mathrm{CO}_{2}$.

\section{Whole-Cell Lysate Kinase Assay}

SH-SY5Y cells were washed with phosphate buffered saline (PBS) and lysed with

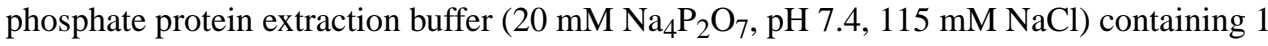
$\mathrm{mM}$ phenylmethanesulfonyl fluoride (PMSF) and a protease inhibitor cocktail. Lysate was diluted with kinase buffer (40 mM Tris, pH 7.5, $20 \mathrm{mM} \mathrm{MgCl}_{2}, 50 \mu \mathrm{M}$ DTT, $400 \mu \mathrm{M}$ ATP) to afford a concentration of $4 \mu \mathrm{g} / \mu \mathrm{L}$ of total protein, and split into aliquots. Recombinant human GSK3 $\beta$ was fortified into lysate aliquots to a final concentration of $0.25 \%$ (wt/wt) of total protein. A lysate aliquot spiked with heat-inactivated GSK3 $\beta$ was used as a negative control. The fortified lysate aliquots were incubated with test sample or 5\% DMSO vehicle at $37{ }^{\circ} \mathrm{C}$ for $2 \mathrm{~h}$ followed by western blot analysis. The GSK $3 \beta$ inhibitor $\mathrm{LiCl}$ was used at 10 $\mathrm{mM}$ as a reference control. 


\section{$A \beta_{42}$ Oligomer Preparation}

The toxic oligomers of $A \beta_{42}$ were prepared as described. ${ }^{54}$ Briefly, lyophilized $A \beta_{42}$ peptide was dissolved in hexafluoroisopropanol, dried under vacuum, and stored at $-20^{\circ} \mathrm{C}$.

Immediately before using, the peptide residue was reconstituted in DMEM/F12 media to make a stock solution at $0.1 \mathrm{mM}$ and incubated at $4{ }^{\circ} \mathrm{C}$ for $24 \mathrm{~h}$ to form diffusible oligomers. $\mathrm{A} \beta_{42}$ oligomers at a final concentration of $10 \mu \mathrm{M}$ were assayed for cell viability

\section{Cell Viability Assay}

SH-SY5Y cells were seeded at a density of $3 \times 10^{5}$ cells $/ \mathrm{mL}$ in a 96 -well plate in DMEM/F12 media containing 1\% FBS to suppress cell proliferation. Cells were incubated under regular culture conditions for attachment. After $24 \mathrm{~h}$ of plating, the cells were pretreated with different concentrations of test samples or the $0.2 \%$ DMSO as a vehicle control for $1 \mathrm{~h}$ and then co-incubated with $10 \mu \mathrm{M} \mathrm{A} \beta_{42}$ for $72 \mathrm{~h}$. After the experimental treatment, the cells were subject to a CellTiter 96 AQueous One Solution Cell Proliferation MTX Assay according to the instruction. $1 \mu \mathrm{M}$ staurosporine was used as a reference control for cytotoxicity, while $10 \mu \mathrm{M}$ TDZD- 8 and $10 \mathrm{mM} \mathrm{LiCl}$ were used as reference controls for GSK3 $\beta$ inhibition. Each data point was collected in triplicate of two independent experiments.

\section{Western Blot Analysis}

SH-SY5Y cells were seeded at a density of $3 \times 10^{5}$ cells $/ \mathrm{mL}$ in a 24 -well plate in DMEM/F12 media containing 1\% FBS. Cells were pretreated with different concentrations of test samples or the $0.2 \%$ DMSO vehicle for $1 \mathrm{~h}$ followed by co-incubation with $10 \mu \mathrm{M}$ $\mathrm{A} \beta_{42}$ for $72 \mathrm{~h}$. The cultures were then washed with PBS and lysed with phosphate protein extraction buffer ( $\left.20 \mathrm{mM} \mathrm{Na}_{4} \mathrm{P}_{2} \mathrm{O}_{7}, \mathrm{pH} 7.4,115 \mathrm{mM} \mathrm{NaCl}\right)$ containing $1 \mathrm{mM} \mathrm{PMSF}$ and a protease inhibitor cocktail. Concentrations of the harvested proteins were determined by Bradford assay. Equal amounts of total proteins for each sample (10 $\mu \mathrm{g}$ per lane) were resolved by $10 \%$ SDS-PAGE and transferred onto PVDF membranes. The membranes were blocked with 5\% BSA overnight and hybridized with primary antibodies against Tau-5 (total tau), Tau pS199/pS202, Tau pS396, GSK3 $\beta$ (total GSK3 $\beta$ ), GSK3 $\beta$ pS9 or $\beta$-actin (loading control) at room temperature for $2 \mathrm{~h}$. After washes, the membranes were incubated with corresponding alkaline phosphatase-conjugated secondary antibodies at room temperature for $1 \mathrm{~h}$, and the immunoreactive bands were detected by the BCIP/NBT reagent. Densitometric analysis was performed on three independent blots per experiment.

\section{Statistical Analysis}

Data were presented as mean \pm SEM. The data were analyzed by one-way ANOVA with Bonferroni's multiple comparison test, Tukey's multiple comparison posthoc test, as well as Student $t$ test. The $p$ values less than 0.05 were considered statistically significant. Analyses were performed using Excel and GraphPad Prism.

\section{Supplementary Material}

Refer to Web version on PubMed Central for supplementary material. 


\section{ACKNOWLEDGMENT}

We thank Dr. J. L. Brewbaker, UH-Manoa, for kindly providing corn silk samples; Dr. J. Yang and Dr. Y. S. Kim, UH-Manoa, for the assistance of cell culture; W. Yoshida, UH-Manoa, for acquiring the NMR spectra.

Funding Sources

This work was supported in part by the National Institute on Minority Health and Health Disparities grant 8G12MD007601 and by the National Institutes of Health grant 5R01AG039468.

\section{ABBREVIATIONS}

CS

AD

$\mathbf{A} \boldsymbol{\beta}_{42}$

NFT

PHF

TPK

MARK

GSK3 $\beta$

CDK5/p25

CDK5/p35

ERK2

JNK1

JNK3

p38a

p38 $\delta$

AKT1

PKA

PKC

p70S6K $\beta$

ROCK1

RSK2

PDK1

CAMKII corn silks

Alzheimer's disease

$\beta$-amyloid fragment peptide 1-42

neurofibrillary tangle

paired helical filament

tau-protein kinase

microtubule affinity-regulating kinase

glycogen synthase kinase 3 beta

cyclin dependent kinase 5 with subunit p25

cyclin dependent kinase 5 with subunit p35

extracellular signal regulated kinase 2

c-Jun N-terminal kinase 1

c-Jun N-terminal kinase 3

p38 mitogen-activated protein kinase 14

p38 mitogen-activated protein kinase 13

v-akt murine thymoma viral oncogene homolog 1

protein kinase A

protein kinase $\mathrm{C}$

p70 ribosomal protein S6 kinase beta

Rho-associated, coiled-coil containing protein kinase 1

ribosomal protein S6 kinase 2

phosphoinositide-dependent kinase 1

$\mathrm{Ca}^{2+} /$ calmodulin-dependent protein kinase II 
CAMKIV

DAPK1

AMPK

CK1

CK2

DNA-PK

PI3K

LC-QTOF-MS

ESI-CID-MS/MS

HPLC

NMR

SDS-PAGE

PDB

SAR
$\mathrm{Ca}^{2+} /$ calmodulin-dependent protein kinase IV

death-associated protein kinase 1

AMP-activated protein kinase

casein kinase 1

casein kinase 2

DNA-dependent protein kinase

phosphoinositide 3-kinase

liquid chromatography-quadrupole time-of-flight-mass spectrometry

electrospray ionization-collision induced dissociationtandem mass spectrometry

high performance liquid chromatography

nuclear magnetic resonance

sodium dodecyl sulfate-polyacrylamide gel electrophoresis

protein data bank

structure-activity relationship

\section{REFERENCES}

(1). Citron M (2010) Alzheimer's disease: Strategies for disease modification, Nat. Rev. Drug Discov 9, 387-398. [PubMed: 20431570]

(2). Querfurth HW, and LaFerla FM (2010) Alzheimer's disease, N. Engl. J. Med 362, 329-344. [PubMed: 20107219]

(3). Conde C, and Caceres A (2009) Microtubule assembly, organization and dynamics in axons and dendrites, Nat. Rev. Neurosci 10, 319-332. [PubMed: 19377501]

(4). Morris M, Maeda S, Vossel K, and Mucke L (2011) The many faces of tau, Neuron 70, 410-426. [PubMed: 21555069]

(5). Ballatore C, Lee VMY, and Trojanowski JQ (2007) Tau-mediated neurodegeneration in Alzheimer's disease and related disorders, Nat. Rev. Neurosci 8, 663-672. [PubMed: 17684513]

(6). Hanger DP, Anderton BH, and Noble W (2009) Tau phosphorylation: The therapeutic challenge for neurodegenerative disease, Trends Mol. Med 15, 112-119. [PubMed: 19246243]

(7). Mazanetz MP, and Fischer PM (2007) Untangling tau hyperphosphorylation in drug design for neurodegenerative diseases, Nat. Rev. Drug Discov 6, 464-479. [PubMed: 17541419]

(8). Hooper C, Killick R, and Lovestone S (2008) The GSK3 hypothesis of Alzheimer's disease, J. Neurochem 104, 1433-1439. [PubMed: 18088381]

(9). Mangialasche F, Solomon A, Winblad B, Mecocci P, and Kivipelto M (2010) Alzheimer's disease: Clinical trials and drug development, Lancet Neurol. 9, 702-716. [PubMed: 20610346]

(10). Huang Y, and Mucke L (2012) Alzheimer mechanisms and therapeutic strategies, Cell 148, 1204-1222. [PubMed: 22424230]

(11). Hasanudin K, Hashim P, and Mustafa S (2012) Corn silk (Stigma maydis) in healthcare: A phytochemical and pharmacological review, Molecules 17, 9697-9715. [PubMed: 22890173] 
(12). Elliger CA, Chan BG, Waiss AC Jr, Lundin RE, and Haddon WF (1980) C-Glycosylflavones from Zea mays that inhibit insect development, Phytochemistry 19, 293-297.

(13). Wang G-Q, Xu T, Bu X-M, and Liu B-Y (2012) Anti-inflammation effects of corn silk in a rat model of carrageenin-induced pleurisy, Inflammation 35, 822-827. [PubMed: 21898269]

(14). Liu J, Wang C, Wang Z, Zhang C, Lu S, and Liu J (2011) The antioxidant and free-radical scavenging activities of extract and fractions from corn silk (Zea mays L.) and related flavone glycosides, Food Chem. 126, 261-269.

(15). Tian J, Chen H, Chen S, Xing L, Wang Y, and Wang J (2013) Comparative studies on the constituents, antioxidant and anticancer activities of extracts from different varieties of corn silk, Food Funct. 4, 1526-1534. [PubMed: 24056502]

(16). Casas MI, Duarte SM, Doseff AI, and Grotewold E (2014) Flavone-rich maize: An opportunity to improve the nutritional value of an important commodity crop, Front. Plant Sci 5, 440. [PubMed: 25250036]

(17). Ferrari A, Hoerndli F, Baechi T, Nitsch RM, and Götz J (2003) $\beta$-Amyloid induces paired helical filament-like tau filaments in tissue culture, J. Biol. Chem 278, 40162-40168. [PubMed: 12893817]

(18). Agholme L, Lindström T, Kågedal K, Marcusson J, and Hallbeck M (2010) An in vitro model for neuroscience: Differentiation of SH-SY5Y cells into cells with morphological and biochemical characteristics of mature neurons, J. Alzheimer's Dis 20, 1069-1082. [PubMed: 20413890]

(19). Datki Z, Papp R, Zádori D, Soós K, Fülöp L, Juhász A, Laskay G, Hetényi C, Mihalik E, Zarándi $M$, and Penke B (2004) In vitro model of neurotoxicity of A $\beta$ 1-42 and neuroprotection by a pentapeptide: Irreversible events during the first hour, Neurobiol. Dis 17, 507-515. [PubMed: 15571986]

(20). Zheng X, Xie Z, Zhu Z, Liu Z, Wang Y, Wei L, Yang H, Yang H, Liu Y, and Bi J (2014) Methyllycaconitine alleviates amyloid- $\beta$ peptides-induced cytotoxicity in SH-SY5Y cells, PLoS ONE 9, e111536. [PubMed: 25360664]

(21). Gray NE, Morré J, Kelley J, Maier CS, Stevens JF, Quinn JF, and Soumyanath A (2014) Caffeoylquinic acids in Centella asiatica protect against amyloid- $\beta$ toxicity, J. Alzheimer's Dis 40, 359-373. [PubMed: 24448790]

(22). Kato T, and Morita Y (1990) C-Glycosylflavones with acetyl substitution from Rumex acetosa L, Chem. Pharm. Bull 38, 2277-2280.

(23). Snook ME, Gueldner RC, Widstrom NW, Wiseman BR, Himmelsbach DS, Harwood JS, and Costello CE (1993) Levels of maysin and maysin analogs in silks of maize germplasm, J. Agric. Food Chem 41, 1481-1485.

(24). Abad-García B, Garmón-Lobato S, Berrueta LA, Gallo B, and Vicente F (2008) New features on the fragmentation and differentiation of $\mathrm{C}$-glycosidic flavone isomers by positive electrospray ionization and triple quadrupole mass spectrometry, Rapid Commun. Mass Spectrom. 22, 18341842. [PubMed: 18470889]

(25). Sassano MF, Doak AK, Roth BL, and Shoichet BK (2013) Colloidal aggregation causes inhibition of G protein-coupled receptors, J. Med. Chem 56, 2406-2414. [PubMed: 23437772]

(26). Feng BY, and Shoichet BK (2006) A detergent-based assay for the detection of promiscuous inhibitors, Nat. Protoc 1, 550-553. [PubMed: 17191086]

(27). Hur E-M, and Zhou F-Q (2010) GSK3 signalling in neural development, Nat. Rev. Neurosci 11, 539-551. [PubMed: 20648061]

(28). Palomo V, Soteras I, Perez DI, Perez C, Gil C, Campillo NE, and Martinez A (2011) Exploring the binding sites of glycogen synthase kinase 3. Identification and characterization of allosteric modulation cavities, J. Med. Chem 54, 8461-8470. [PubMed: 22050263]

(29). Eldar-Finkelman H, and Martinez A (2011) GSK-3 inhibitors: Preclinical and clinical focus on CNS, Front. Mol. Neurosci 4, 32. [PubMed: 22065134]

(30). Peng J, Kudrimoti S, Prasanna S, Odde S, Doerksen RJ, Pennaka HK, Choo Y-M, Rao KV, Tekwani BL, Madgula V, Khan SI, Wang B, Mayer AMS, Jacob MR, Tu LC, Gertsch J, and Hamann MT (2010) Structure-activity relationship and mechanism of action studies of manzamine analogues for the control of neuroinflammation and cerebral infections, J. Med. Chem 53, 61-76. [PubMed: 20017491] 
(31). Bertrand JA, Thieffine S, Vulpetti A, Cristiani C, Valsasina B, Knapp S, Kalisz HM, and Flocco M (2003) Structural characterization of the GSK-3 $\beta$ active site using selective and non-selective ATP-mimetic inhibitors, J. Mol. Biol 333, 393-407. [PubMed: 14529625]

(32). Forlenza OV, De-Paula VJR, and Diniz BSO (2014) Neuroprotective effects of lithium: Implications for the treatment of Alzheimer's disease and related neurodegenerative disorders, ACS Chem. Neurosci 5, 443-450. [PubMed: 24766396]

(33). Ilouz R, Kowalsman N, Eisenstein M, and Eldar-Finkelman H (2006) Identification of novel glycogen synthase kinase- $3 \beta$ substrate-interacting residues suggests a common mechanism for substrate recognition, J. Biol. Chem 281, 30621-30630. [PubMed: 16893889]

(34). Busciglio J, Lorenzo A, Yeh J, and Yankner BA (1995) $\beta$-Amyloid fibrils induce tau phosphorylation and loss of microtubule binding, Neuron 14, 879-888. [PubMed: 7718249]

(35). Takashima A (2006) GSK-3 is essential in the pathogenesis of Alzheimer's disease, J. Alzheimer's Dis 9, 309-317. [PubMed: 16914869]

(36). Ma R, Xiong N, Huang C, Tang Q, Hu B, Xiang J, and Li G (2009) Erythropoietin protects PC12 cells from $\beta$-amyloid $25-35$-induced apoptosis via PI3K/Akt signaling pathway, Neuropharmacology 56, 1027-1034. [PubMed: 19268480]

(37). Li L, Liu Z, Liu J, Tai X, Hu X, Liu X, Wu Z, Zhang G, Shi M, and Zhao G (2013) Ginsenoside $\mathrm{Rd}$ attenuates beta-amyloid-induced tau phosphorylation by altering the functional balance of glycogen synthase kinase 3beta and protein phosphatase 2A, Neurobiol. Dis 54, 320-328. [PubMed: 23321003]

(38). Domínguez JM, Fuertes A, Orozco L, del Monte-Millán M, Delgado E, and Medina M (2012) Evidence for irreversible inhibition of glycogen synthase kinase- $3 \beta$ by tideglusib, J. Biol. Chem 287, 893-904. [PubMed: 22102280]

(39). Martinez A, Alonso M, Castro A, Dorronsoro I, Gelpí JL, Luque FJ, Pérez C, and Moreno FJ (2005) SAR and 3D-QSAR studies on thiadiazolidinone derivatives: Exploration of structural requirements for glycogen synthase kinase 3 inhibitors, J. Med. Chem 48, 7103-7112. [PubMed: 16279768]

(40). Yankner BA, Duffy LK, and Kirschner DA (1990) Neurotrophic and neurotoxic effects of amyloid $\beta$ protein: Reversal by tachykinin neuropeptides, Science 250, 279-282. [PubMed: 2218531]

(41). McMullen MD, Byrne PF, Snook ME, Wiseman BR, Lee EA, Widstrom NW, and Coe EH (1998) Quantitative trait loci and metabolic pathways, Proc. Natl. Acad. Sci. U.S.A 95, 1996-2000. [PubMed: 9482823]

(42). Baptista FI, Henriques AG, Silva AMS, Wiltfang J, and da Cruz e Silva OAB (2014) Flavonoids as therapeutic compounds targeting key proteins involved in Alzheimer's disease, ACS Chem. Neurosci 5, 83-92. [PubMed: 24328060]

(43). Williams P, Sorribas A, and Howes M-JR (2011) Natural products as a source of Alzheimer's drug leads, Nat. Prod. Rep 28, 48-77. [PubMed: 21072430]

(44). Kan A, Orhan I, Coksari G, and Sener B (2012) In-vitro neuroprotective properties of the Maydis stigma extracts from four corn varieties, Int. J. Food Sci. Nutr 63, 1-4.

(45). Choi DJ, Kim S-L, Choi JW, and Park YI (2014) Neuroprotective effects of corn silk maysin via inhibition of H2O2-induced apoptotic cell death in SK-N-MC cells, Life Sci. 109, 57-64. [PubMed: 24928367]

(46). Pacifico S, Scognamiglio M, D’Abrosca B, Piccolella S, Tsafantakis N, Gallicchio M, Ricci A, and Fiorentino A (2010) Spectroscopic characterization and antiproliferative activity on HepG2 human hepatoblastoma cells of flavonoid C-glycosides from Petrorhagia velutina, J. Nat. Prod 73, 1973-1978. [PubMed: 21080643]

(47). Yuan L, Wang J, Xiao H, Xiao C, Wang Y, and Liu X (2012) Isoorientin induces apoptosis through mitochondrial dysfunction and inhibition of PI3K/Akt signaling pathway in HepG2 cancer cells, Toxicol. Appl. Pharmacol 265, 83-92. [PubMed: 23026832]

(48). Yang S, Liu W, Lu S, Tian Y-Z, Wang W-Y, Ling T-J, and Liu R-T (2016) A novel multifunctional compound camellikaempferoside $B$ decreases $A \beta$ production, interferes with $A \beta$ aggregation, and prohibits $\mathrm{A} \beta$-mediated neurotoxicity and neuroinflammation, ACS Chem. Neurosci 7, 505-518. [PubMed: 27015590] 
(49). Anighoro A, Bajorath J, and Rastelli G (2014) Polypharmacology: Challenges and opportunities in drug discovery, J. Med. Chem 57, 7874-7887. [PubMed: 24946140]

(50). Zhao S, and Iyengar R (2012) Systems pharmacology: Network analysis to identify multiscale mechanisms of drug action, Annu. Rev. Pharmacol. Toxicol 52, 505-521. [PubMed: 22235860]

(51). Higa JK, Liang Z, Williams PG, and Panee J (2012) Phyllostachys edulis compounds inhibit palmitic acid-induced monocyte chemoattractant protein 1 (MCP-1) production, PLoS ONE 7, e45082. [PubMed: 23028772]

(52). Zegzouti H, Zdanovskaia M, Hsiao K, and Goueli SA (2009) ADP-Glo: A bioluminescent and homogeneous ADP monitoring assay for kinases, Assay Drug Dev. Technol 7, 560-572. [PubMed: 20105026]

(53). Trott O, and Olson AJ (2010) AutoDock Vina: Improving the speed and accuracy of docking with a new scoring function, efficient optimization, and multithreading, J. Comput. Chem 31, 455461. [PubMed: 19499576]

(54). Dahlgren KN, Manelli AM, Stine WB, Baker LK, Krafft GA, and LaDu MJ (2002) Oligomeric and fibrillar species of amyloid- $\beta$ peptides differentially affect neuronal viability, J. Biol. Chem 277, 32046-32053. [PubMed: 12058030] 


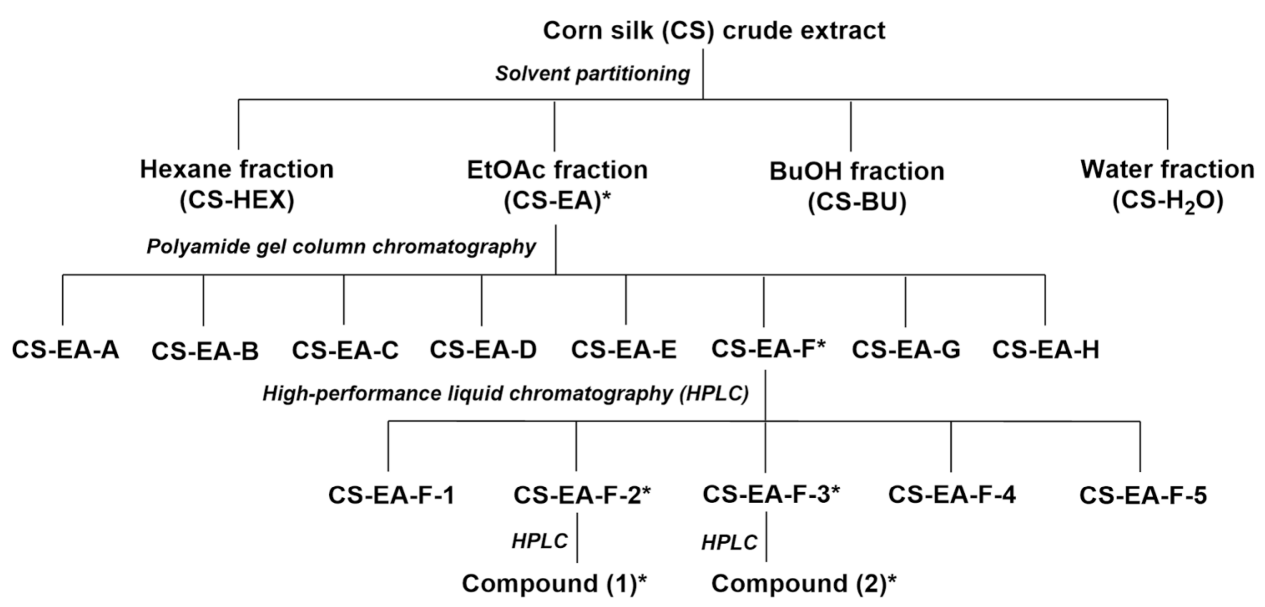

Figure 1.

Schematic of GSK3 $\beta$ assay guided fractionation of $\mathbf{1}$ and $\mathbf{2}$ from a corn silk (CS) Zea mays L. extract. The crude extract was subject to successive partitioning using $n$-hexane, ethyl acetate (EtOAc), $n$-butanol and $\mathrm{H}_{2} \mathrm{O}$ to yield four primary fractions. The fractions with the most potent GSK3 $\beta$ inhibition were further subject to flash column chromatography on a polyamide column using a step gradient of $\mathrm{MeOH}$ in $\mathrm{H}_{2} \mathrm{O}$, affording eight fractions (A-H). Separation of fraction F (CS-EA-F) by HPLC afforded five subfractions, whose GSK3 $\beta$ inhibitory activities were concentrated in subfraction-2 (CS-EA-F-2) and subfraction-3 (CSEA-F-3). HPLC purification led to the isolation of compound $\mathbf{1}$ and $\mathbf{2}$. *Fractions showed > $40 \%$ inhibition at $100 \mu \mathrm{g} / \mathrm{mL}$ in the GSK3$\beta$ kinase assay. 
A
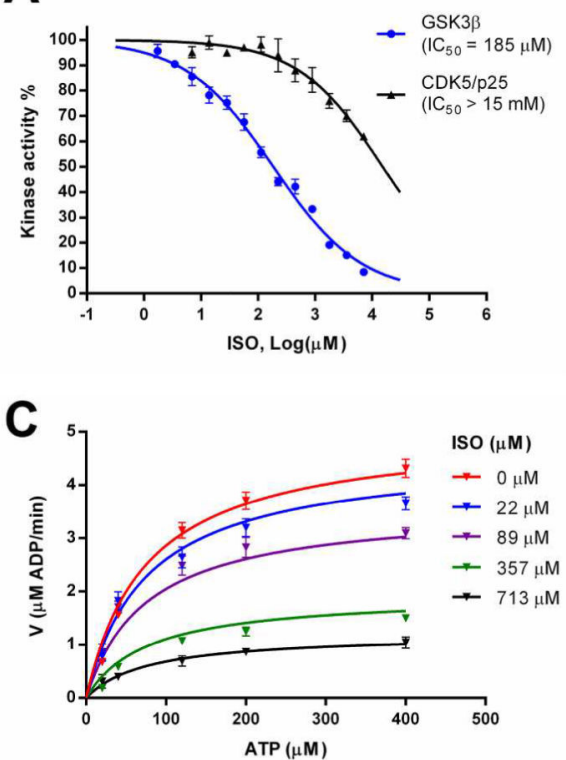

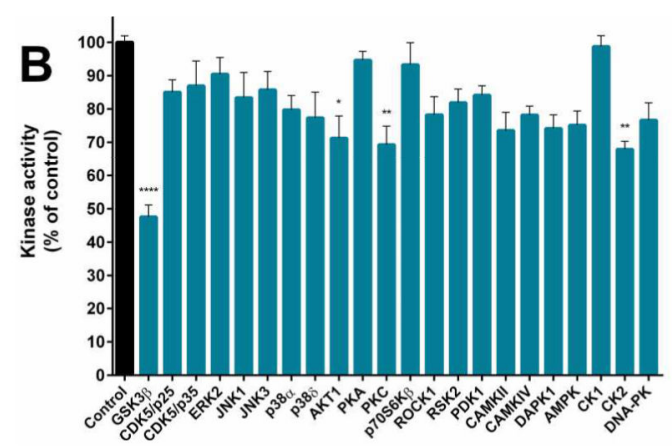

D

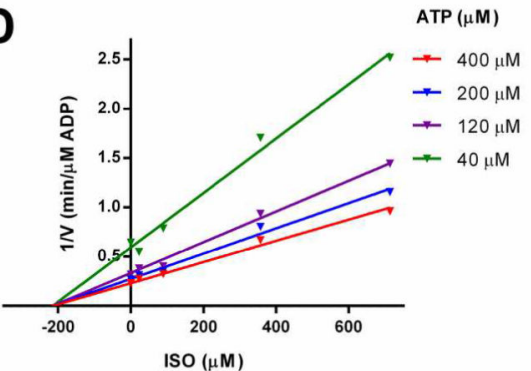

Figure 2.

Isoorientin (1) selectively inhibits GSK3 $\beta$ via an ATP noncompetitive mechanism. (A) 1 inhibited GSK3 $\beta$ activity with an $\mathrm{IC}_{50}$ value of $185 \pm 25 \mu \mathrm{M}$. The $\mathrm{IC}_{50}$ value of $\mathbf{1}$ to $\mathrm{CDK} 5 / \mathrm{p} 25$ was $>15 \mathrm{mM}$. Results were presented as the percentage of the kinase activity relative to control (5\% DMSO vehicle). Inhibition curves were analyzed by non-linear regression. (B) Effect of $\mathbf{1}$ on the activities of 22 protein kinases. Protein kinases were assayed in the presence of $224 \mu \mathrm{M} 1$ or control (5\% DMSO vehicle). (C) GSK3 $\beta$ inhibitory kinetics in vitro, when GSK3 $\beta$ substrate GS2 was kept constant at $17 \mu \mathrm{M}$. GSK3 $\beta$ activity was determined by increasing concentrations of 1 in the presence of varying ATP concentrations. The lines represented the result of a non-linear regression analysis of the entire data set using a best-fit kinetic model for enzyme inhibition. The analysis showed a noncompetitive inhibition of ATP with a $K_{\mathrm{i}}$ of $210 \pm 22 \mu \mathrm{M}$, and a $K_{\mathrm{m}}$ of $76 \pm 9 \mu \mathrm{M}$. (D) Dixon plots of GSK3 $\beta$ activity in the presence of varying concentrations of ATP versus 1. The lines were linear regression plotting of 1/V against concentration of $\mathbf{1}$ at a given concentration of ATP. Intersecting at the same point on the $\mathrm{X}$ axis indicated a noncompetitive inhibition with respect to ATP. Data were means of quadruplicate of each of two independent experiments with \pm SEM. ${ }^{*} p<0.05,{ }^{* *} p<0.01,{ }^{* * *} p<0.001,{ }^{* * * *} p<$ 0.0001 relative to control. ISO, isoorientin. 

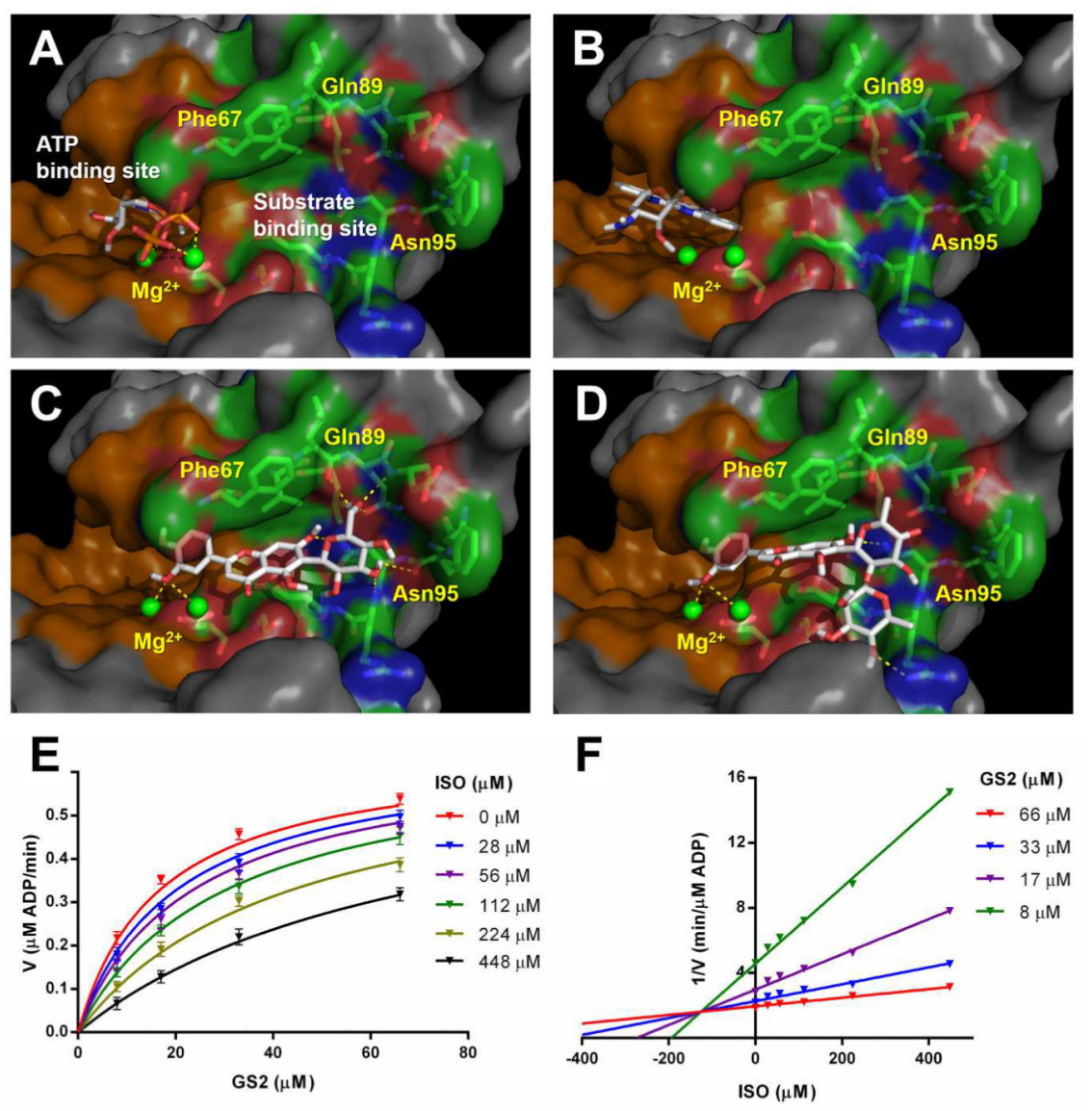

Figure 3.

Isoorientin (1) is a substrate competitive inhibitor of GSK3 $\beta$. Predicted docking structures of ATP (A), staurosporine (B), 1 (C) and 2 (D) with GSK3 $\beta$. Surface representation of the ATP-binding site of GSK3 $\beta$ is shown in orange, the substrate-binding site of GSK3 $\beta$ is shown in green. Within substrate-binding site, surface features are shown with acidic residues in red, basic residues in blue, hydrophobic residues in green. Magnesium ions are shown as bright green spheres. The dotted lines represent interactions with magnesium ions and hydrogen bonds with side chain residues of GSK3 $\beta$. (E) GSK3 $\beta$ inhibitory kinetics in vitro, when ATP was kept constant at $25 \mu \mathrm{M}$. GSK3 $\beta$ activity was determined by increasing concentrations of $\mathbf{1}$ in the presence of varying concentrations of kinase substrate GS2. The lines represented the result of a non-linear regression analysis of the entire data set using a best-fit kinetic model for enzyme inhibition. The analysis showed a competitive inhibition of GS2 with a $K_{\mathrm{i}}$ of $125 \pm 13 \mu \mathrm{M}$, and a $\mathrm{V}_{\max }$ of $0.66 \pm 0.02 \mu \mathrm{M} / \mathrm{min}$. (F) Dixon plots of GSK $3 \beta$ activity in the presence of varying concentrations of GS2 versus 1 . The lines were linear regression plotting of 1/V against concentration of $\mathbf{1}$ at a given concentration of GS2. Intersecting point above the $\mathrm{X}$ axis indicated a competitive inhibition with respect to substrate GS2. Data were means of quadruplicate of each of two independent experiments with \pm SEM. ISO, isoorientin. 

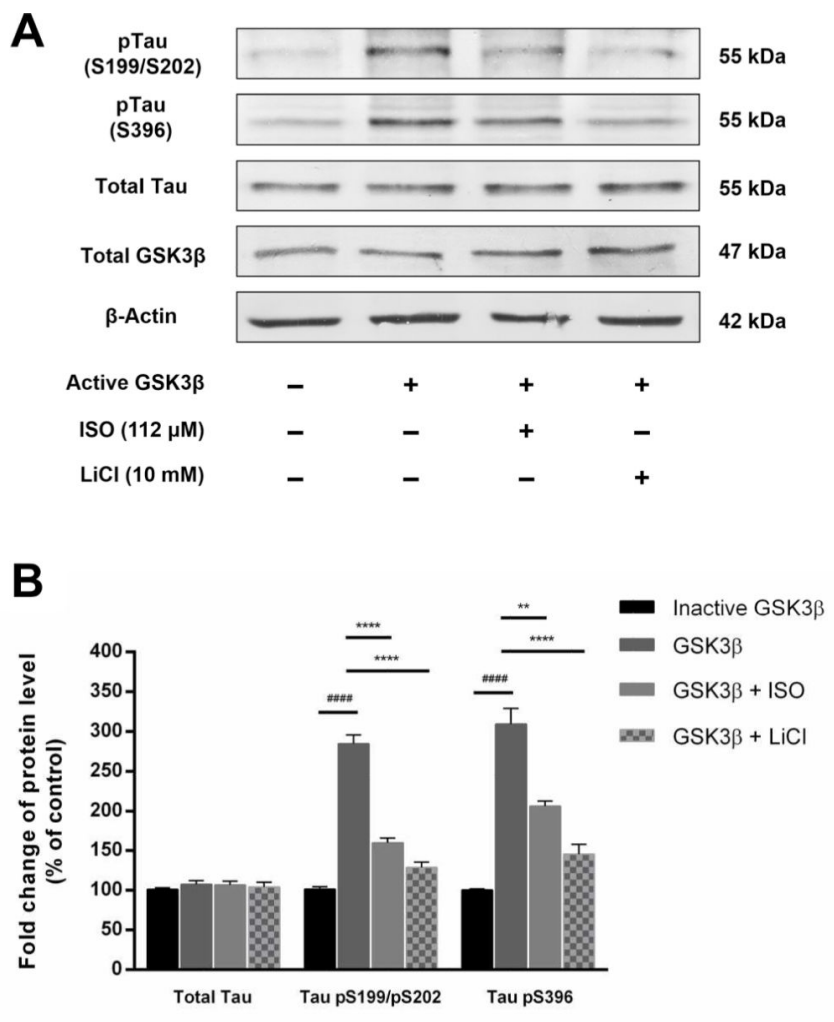

Figure 4.

Isoorientin (1) attenuates GSK3 $\beta$ mediated tau phosphorylation in a SH-SY5Y whole-cell lysate kinase assay. (A) Cell lysate aliquots were spiked with $0.25 \%$ (wt/wt) GSK3 $\beta$, and incubated with $112 \mu \mathrm{M} \mathrm{1,10} \mathrm{mM} \mathrm{LiCl}$ or $5 \%$ DMSO vehicle in a kinase buffer at $37{ }^{\circ} \mathrm{C}$ for $2 \mathrm{~h}$. Immunoblot analysis was performed with antibodies against Tau-5, Tau pS199/pS202, pS396 and GSK3 $\beta$. $\beta$-Actin level was used as a protein loading control. (B) Densitometric analysis of western blotting for tau protein levels. Optical densities were normalized to $\beta$ actin and fold changes were calculated relative to the control with $\pm \operatorname{SEM}(n=3)$. ${ }^{\# \# \# ~} p<$ 0.0001 relative to inactive GSK3 $\beta$ spiked control; ${ }^{* *} p<0.01,{ }^{* * *} p<0.001,{ }^{* * * *} p<0.0001$ relative to the active GSK3 $\beta$ spiked control. ISO, isoorientin. 

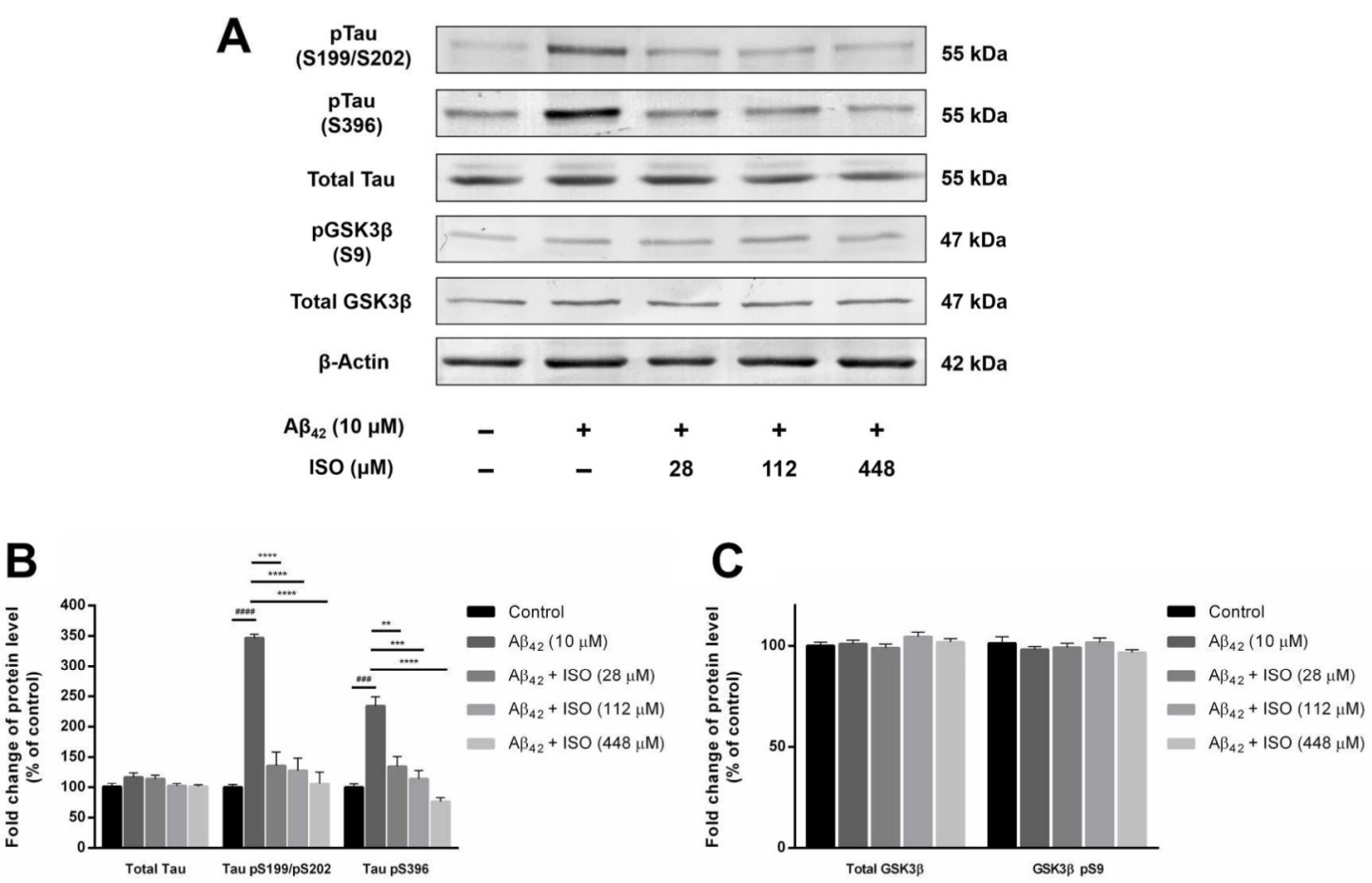

Figure 5.

Isoorientin (1) attenuates $A \beta_{42}$ induced tau phosphorylation in SH-SY5Y cells. (A) Cells were pretreated with varying concentrations of 1 or $0.2 \%$ DMSO vehicle for $1 \mathrm{~h}$ followed by $10 \mu \mathrm{M} \mathrm{A} \beta_{42}$ treatment and incubated for $72 \mathrm{~h}$. Immunoblot analysis was performed with antibodies against Tau-5, Tau pS199/pS202, Tau pS396, GSK3 $\beta$, and GSK3 $\beta$ pS9. $\beta$-Actin level was used as a protein loading control. (B) Densitometric analysis of western blotting for tau protein levels. (C) Densitometric analysis of western blotting for GSK3 $\beta$ levels.

Optical densities were normalized to $\beta$-actin and fold changes were calculated relative to the

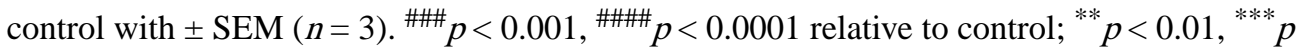
$<0.001,{ }^{* * * *} p<0.0001$ relative to the $10 \mu \mathrm{M} \mathrm{A} \beta_{42}$ treatment. ISO, isoorientin. 

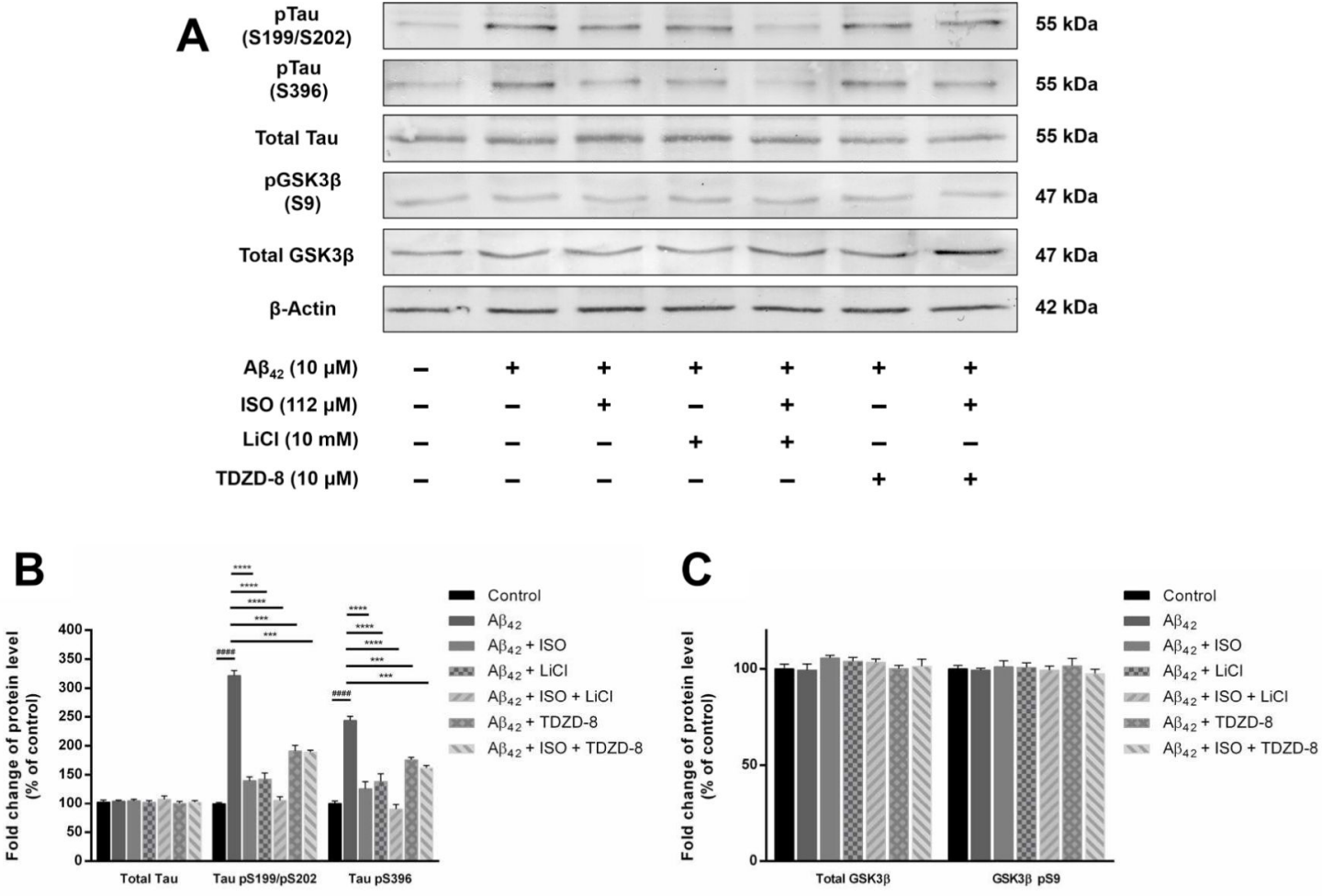

Figure 6.

Isoorientin (1) attenuates $A \beta_{42}$ induced tau phosphorylation by inhibiting GSK3 $\beta$ in SHSY5Y cells. (A) Cells were pretreated with individual inhibitor $(112 \mu \mathrm{M}$ for $1 ; 10 \mathrm{mM}$ for $\mathrm{LiCl} ; 10 \mu \mathrm{M}$ for TDZD-8) or a combination (1/LiCl or 1/TDZD-8) for $1 \mathrm{~h}$ followed by 10 $\mu \mathrm{M} \mathrm{A} \beta_{42}$ treatment and incubated for $72 \mathrm{~h}$. Immunoblot analysis was performed with antibodies against Tau-5, Tau pS199/pS202, Tau pS396, GSK3 $\beta$, and GSK3 $\beta$ pS9. $\beta$-Actin level was used as a protein loading control. (B) Densitometric analysis of western blotting for tau protein levels. (C) Densitometric analysis of western blotting for GSK3 $\beta$ levels.

Optical densities were normalized to $\beta$-actin and fold changes were calculated relative to the control with $\pm \operatorname{SEM}(n=3) .{ }^{\# \# \#} p<0.0001$ relative to control; ${ }^{* * *} p<0.001,{ }^{* * * *} p<0.0001$ relative to the $10 \mu \mathrm{MA} \beta_{42}$ treatment. ISO, isoorientin. 

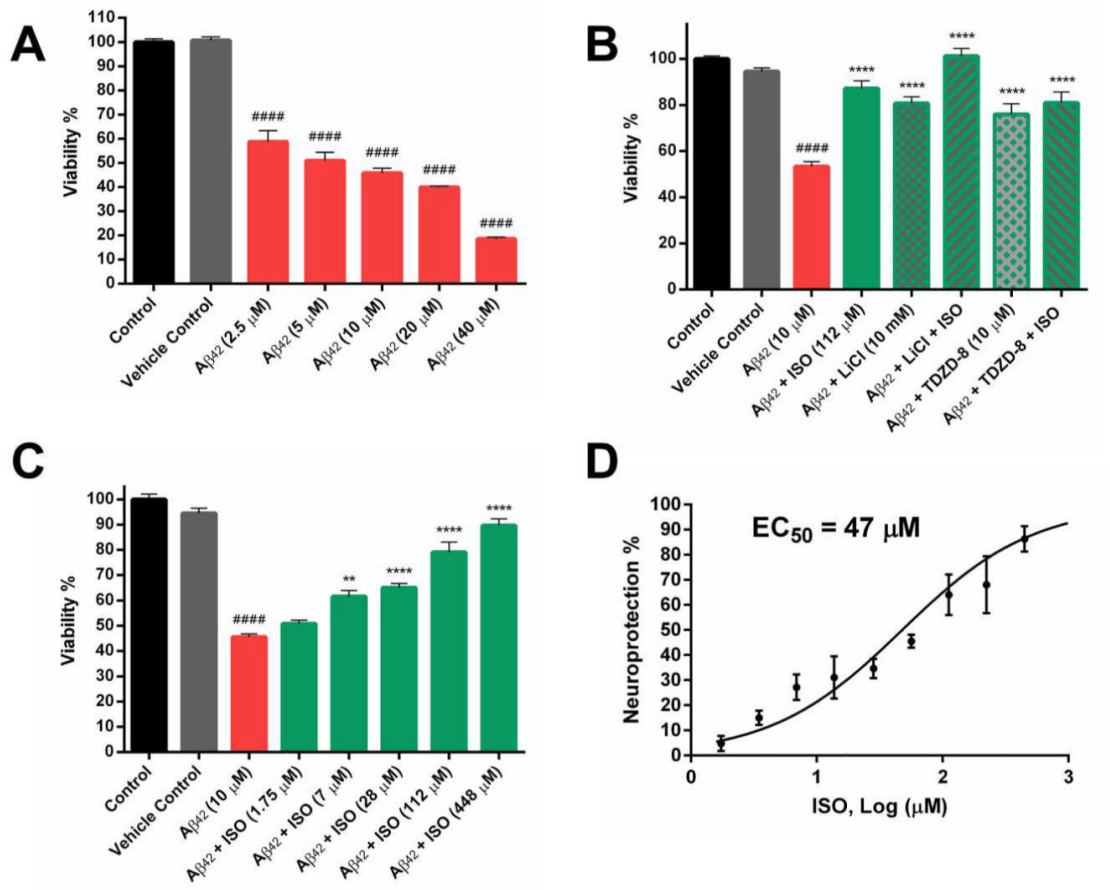

D

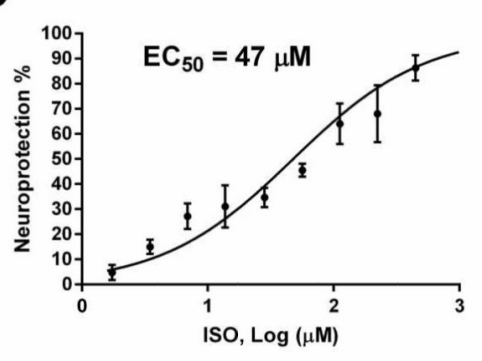

$\mathbf{E}$

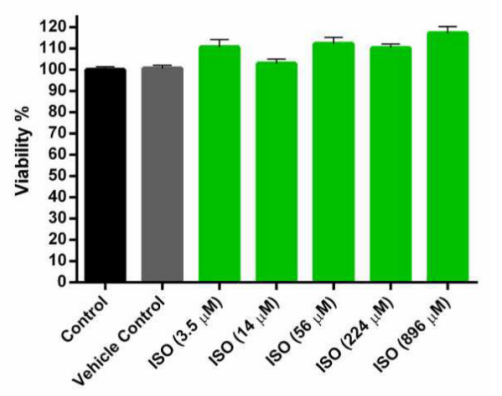

Figure 7.

Isoorientin (1) alleviates $A \beta_{42}$ induced neurotoxicity in SH-SY5Y cells. (A) $A \beta_{42}$ induced neurotoxicity in SH-SY5Y cells. Cells were treated with varying concentrations of $A \beta_{42}$ or $0.2 \%$ DMSO vehicle and incubated for $72 \mathrm{~h}$. Cell viability was determined using the MTX assay. (B) Comparison of neuroprotection of $\mathbf{1}, \mathrm{LiCl}$ and TDZD-8 in SH-SY5Y cells. Cells were pretreated with $\mathbf{1}(112 \mu \mathrm{M}), \mathrm{LiCl}(10 \mathrm{mM})$, TDZD-8 $(10 \mu \mathrm{M})$ or a combination $(\mathbf{1} / \mathrm{LiCl}$ or 1/TDZD-8) for $1 \mathrm{~h}$ followed by $10 \mu \mathrm{M} \mathrm{A} \beta_{42}$ treatment and incubated for $72 \mathrm{~h}$. (C) Cells were pretreated with varying concentrations of 1 or $0.2 \%$ DMSO vehicle for $1 \mathrm{~h}$ followed by $10 \mu \mathrm{M} \mathrm{A} \beta_{42}$ treatment and incubated for $72 \mathrm{~h}$. (D) 1 inhibited neurotoxicity induced by 10 $\mu \mathrm{M} \mathrm{A} \beta_{42}$ with an $\mathrm{EC}_{50}$ value of $47 \pm 22 \mu \mathrm{M}$. Results were presented as the percentage of the neuroprotective activity relative to control (100\%) and $10 \mu \mathrm{M} \mathrm{A} \beta_{42}$ treatment $(0 \%)$.

Neuroprotection curve was analyzed by non-linear regression. (E) Cytotoxicity assessment of $\mathbf{1}$ in SH-SY5Y cells. Cells were treated with varying concentrations of 1 or $0.2 \%$ DMSO vehicle and incubated for $72 \mathrm{~h}$. Data were means of triplicate of each of two independent

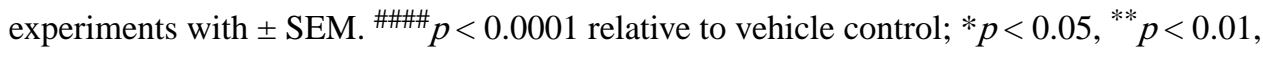
${ }^{* * *} p<0.001,{ }^{* * * *} p<0.0001$ relative to the $10 \mu \mathrm{M} \mathrm{A} \beta_{42}$ treatment. ISO, isoorientin. 

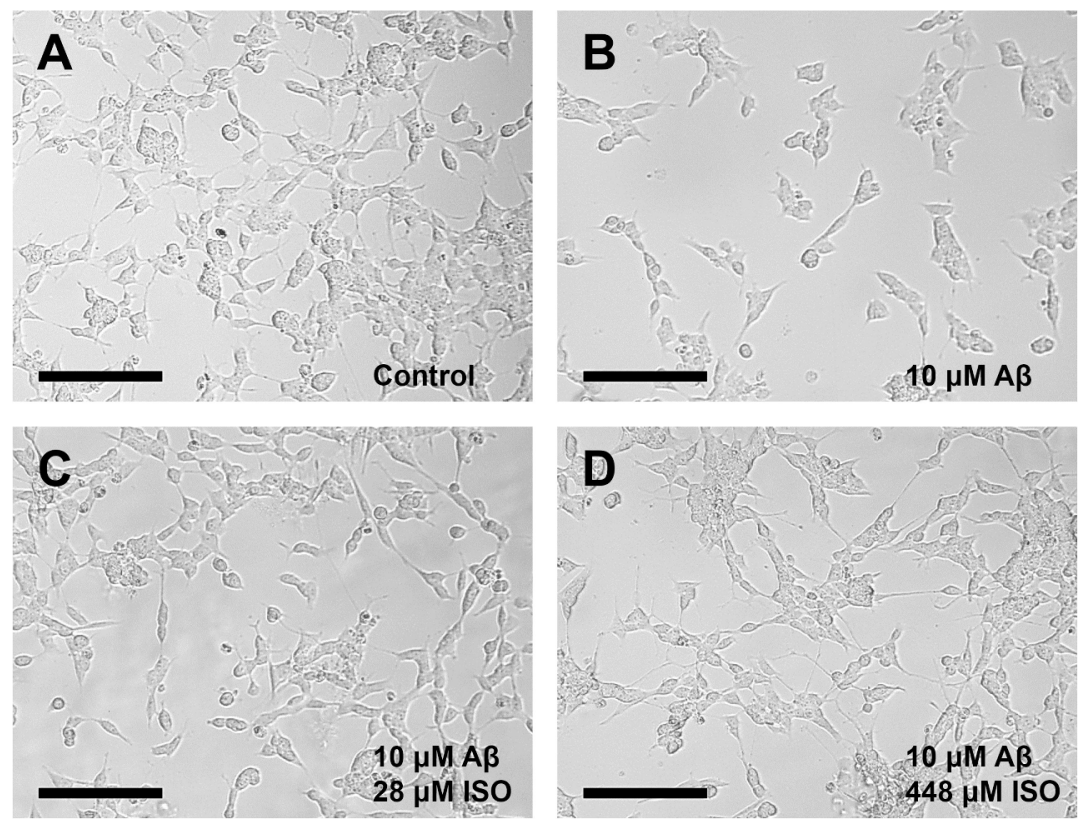

Figure 8.

Morphological changes of SH-SY5Y cells after treatment for $72 \mathrm{~h}$. (A) $0.2 \%$ DMSO treatment as vehicle control. Differentiated cells with extended axons and dendrites. (B) 10 $\mu \mathrm{M} \mathrm{A} \beta_{42}$ treatment. Impaired and nondifferentiated cells with retracted neurites. (C) Pretreatment of $28 \mu \mathrm{M} 1$ followed by $10 \mu \mathrm{M} \mathrm{A} \beta_{42}$ treatment. Partial differentiated cells with extended neurites. (D) Pretreatment of $448 \mu \mathrm{M} 1$ followed by $10 \mu \mathrm{M} \mathrm{A} \beta_{42}$ treatment. Protected differentiated cells with extended axons and dendrites. Micrographs represent the average morphologic characteristics of cell cultures under a given condition of 4-6 experimental replicates. Scale bar $=100 \mu \mathrm{m}$. ISO, isoorientin. 
Table 1.

Inhibitory activity of CS extracts against GSK3 $\beta$

\begin{tabular}{ll}
\hline Sample ID & $\underline{\text { Inhibitory Activity \% ( } \mathbf{S} \text { SEM \%) }}$ \\
\hline CS-EA & $\mathbf{1 0 0} \boldsymbol{\mu g} / \mathbf{m L}$ \\
CS-EA-F & $42.7 \pm 1.0$ \\
CS-EA-F-1 & $44.5 \pm 2.3$ \\
CS-EA-F-2 (Compound $\mathbf{1})$ & $48.4 \pm 2.2$ \\
CS-EA-F-3 (Compound 2$)$ & $41.5 \pm 1.4$ \\
CS-EA-F-4 & $32.3 \pm 3.0$ \\
CS-EA-F-5 & $16.8 \pm 1.3$ \\
Staurosporine (reference) & $100.9 \pm 1.6$ \\
\hline
\end{tabular}

